\title{
Eating from the Wild:
}

\section{Turumbu Indigenous Knowledge on Non-Cultivated Edible Plants, Tshopo District, DRCongo}

\author{
Céline Termote ${ }^{1}$, Patrick Van Damme ${ }^{1}$ and Dhed'a Djailo Benoît ${ }^{2}$ \\ ${ }^{1}$ Laboratory of Tropical and Subtropical Agronomy and Ethnobotany, University of Ghent, \\ Coupure links 653, 9000 Gent, Belgium, Tel: +32 92646089, Celine.Termote@ugent.be, \\ Patrick.VanDdamme@ugent.be
}

2Laboratory of Genetics, $\underline{P} p l a n t$ Iimprovement and B Bbiotechnology, Faculty of Science, University of Kisangani, BP 2012 Kisangani, DRCongo, Tel : +243 998609315, Dhedadjailo@yahoo.fr

\section{ABSTRACT}

Documenting and revalorizing the rapidly disappearing indigenous knowledge on wild edible plants is essential to promote health and preserve diversity. Focus group discussions were organized within 3 Turumbu-villages to document wild foods known, availability, preparation methods and uses. Preferences in taste, commercial, nutritional and cultural value, were discussed during participatory ranking exercises. Results show 85 species within 70 genera and $45 \underline{4}$ families. Fruits of Anonidium manni and Landolphia owariensis, and (unfolded) leaves of Megaphrynium macrostachyum and Talinum triangulare are most appreciated. Inventories and preference rankings should be completed with nutritional analyses and market studies to set priorities for participatory domestication.

KEYWORDS Domestication, Ethnobotany, Wild Edible Plants, Under-Utilized Crops 


\section{INTRODUCTION}

Biodiversity conservation is of utmost importance for agriculture and world food supply. However, existing biodiversity is still under-utilized to expand food production. About 30,000 of the more than 250,000 currently described plant species are edible, whereas about 7,000 have been cultivated or collected by humans for food at one time or another (FAO, 1997). Several thousands of species may thus be considered to contribute to food security, but the value of many species is under-estimated. Data on national food energy supplies aggregated at global level show that only about 30 species provide 95\% of the dietary energy or protein needs of the world (FAO, 1997). Considering national levels, about 103 (PrescottAllen and \& Prescott-Allen, 1990) to 120 (FAO, 1997) plant species are found to 'feed the world.’

Until now, Africa has been the source of only a few food crops with 'universal' importance (sorghum, oil palm and upland rice), besides some crops with local or regional importance such as yam, cowpea, African eggplants or date palm. There exist, however, a number of other useful species that are only known and used by local communities (Van Damme \& Termote, 2008).

Knowledge on wild edible plants (WEPs) in Africa has been developed during centuries of trial and error, and transmitted over generations (Malaisse and $\&$ Parent, 1985). In many areas, WEPs play a major role in supplementing staples with micronutrients (Grivetti and\&

Ogle, 2000; Herzog et al., 1994; Maundu, 1996) or constitute a 'safety net' during periods of food shortage (Keller et al., 2006, Malaisse and $\&$ Parent, 1985; Shackleton and $\&$ Shackleton, 2004; Van Damme, 1998). However, social change and acculturation processes prevailed in Africa for some time now. Knowledge on WEPs is declining and even disappearing with increasing contact with modernization and western lifestyles (Keller et al., 2006; Lykke et al., 2002; Maundu, 1997; Ogoye-Ndegwa and\& Aagaard-Hansen, 2003). 
Traditional leafy vegetables are often associated with poor rural lifestyle and low status. This leads to a general decline in their use when people can afford other foods (Chweya and $\&$ Eyzaguirre 1999; Clark et al., 2004; Lykke et al. 2002). Formerly well-balanced diets are disturbed when traditional products are replaced by imported or newly introduced species, whereby deficiencies in nutrients may develop (Herzog et al., 1994; Lykke et al., 2002; Weinberger and\& $\&$ Swai, 2006).

In addition, replacing traditional foods by 'modern feeding habits' also results in the loss of genetic diversity in traditional food species and a decline in cultural diversity (Maundu, 1996). Documenting and revalorizing the indigenous knowledge on WEPs is thus urgently needed to maintain and promote nutritional health and to preserve genetic and cultural diversity (Terashima and\& Ichakawa, 2003). Moreover, some WEPs may offer good opportunities for commercialization and niche market development, and thus income generation, if properly exploited (Weinberger and $\&$ Swai, 2006).

Until now, only a few fragmented studies concerning WEPs were conducted in Kisangani and surroundings (Bokdam and \& Droogers, 1975; Bola and\& Szafranski, 1991; Liengola, 2001; Mosango and $\&$ Isosi, 1998; Mosango and $\&$ Szafranski, 1985; Nyakabwa et al., 1990; Kawukpa \&and Angoyo, 1994). To (re)valorise traditional knowledge on local WEPs, University of Ghent, in collaboration with University of Kisangani, carried out a WEP-project in the District Tshopo (2004 - 2010). The project objectives are to (1) inventory all WEPs known and used in the District; (2) analyse their nutritional value; and (3) study their socioeconomic and cultural importance, with the overall aim to select $\underline{5 \text { to }} 10$ priority species for participatory domestication and development. The research is executed in a participatory way to take into account local people's opinions in the choice of species for domestication in addition to nutritional and commercial characteristics of the species. 
The objectives of this initial study were to 1) inventory WEPs known and used by the Turumbu, one of the major ethnic groups in the district; and 2) document local preferences in taste and economic, nutritional and socio-cultural values of the WEPs.

Scientific and vernacular names, plant parts used, modes of preparation, specific uses, seasonality patterns in collection and use, and commercialisation possibilities of the WEPs are presented here, together with the results of participatory ranking exercises.

\section{STUDY AREA AND POPULATION}

\section{Tshopo District and 'Collectivité Turumbu'}

Tshopo District, situated in the Oriental Province of the DRCongo, includes 7 territories. The Isangi territory comprises 13 'Collectivités,' operational units at the basis of the hierarchical administration system. The Turumbu live in the 'Collectivité Turumbu,' limited in the north by the Banalia Territory and Aruwimi river, in the east by the Lindi river, in the south by the Congo river and in the west by the Basoko Territory (fig. 1).

Data on surface area or population numbers of the 'Collectivité' are contradictory: $4600 \mathrm{~km}^{2}$ with 40,421 inhabitants on the $1^{\text {st }}$ of July 2004 according to the National Institute of Statistics (Ministère du Plan, 2005) or 3674 km² with 61,905 inhabitants in 2007 according to the Isangi Territory Report (2008).

The hot and humid climate is classified as Af in Köppen’s typology. Annual rainfall in Yangambi amounts to $1828 \mathrm{~mm}$ (PNUD/UNOPS, 1998) and is well-distributed over the whole year (Libendele, 1976). The mean temperature of $23.5^{\circ} \mathrm{C}$ shows very small annual variations (PNUD/UNOPS, 1998).

Tshopo District is situated in the Guineo-Congolian regional center of endemism with mixed moist semi-evergreen forests (White, 1983). The Yangambi biosphere reserve, covering more than half of the 'Collectivité Turumbu,' is dominated by secondary forests with 
Pycnanthus angolensis (Welw.) Warb. and Fagara macrophylla Engl., mixed semi-deciduous secondary rain forests, primary rain forests with Gilbertiodendron dewevrei (De Wild.) J.Léonard, climax forests with Brachystegia laurentii (De Wild.) Louis ex Hoyle and marshland forests (UNESCO, 2008).

\section{The Turumbu}

The Turumbu and their culture have hardly been studied. Their principal activity is agriculture complemented by hunting, fishing, gathering and cattle-raising. The Turumbu are also specialized in handicrafts such as vans, baskets, mortars and canoes. Traditionally, huts are constructed using clay and leaves. Only $8 \%$ of houses are constructed in durable materials (bricks and corrugated iron) (Kienia’h Bikitwa, 1999).

Since the colonial period, the Turumbu practice a mixed cropping system comprising rice, maize, cassava and plantains (Ntamulyango, 1975).

Their main meal consists of cassava and/or plantains: boiled cassava tubers, 'chikwangue' (cassava paste), 'fufu‘ (paste made of cassava flour), 'lituma’ (pounded plantains and/or cassava) or 'makemba' (boiled plantain) (Tshibaka-Mukendi, 1975; own observations), combined with leafy vegetables such as cassava leafs ('pondu’), amaranth ('muchicha'), spinach ('ndunda') or sweet potato leaves ('matembele'). According to the season, this is supplemented with products from hunting, fishing and gathering (plants, mushrooms, caterpillars, ants, honey, etc.). The main fat source is palmoil. Generally, only one meal per day is taken in the afternoon or evening. In the morning, leftovers from the previous day can be warmed up (Tshibaka-Mukendi, 1975).

A survey conducted in 1995-1996 (before the 1996 - 2003 civil strife) showed that, over the whole Oriental Province, the mean energy content of the diet was 1758.24 kcal/inhabitant/day, far below the $2300 \mathrm{kcal}$ recommended by FAO (PNUD/UNOPS, 1998). The diet, mainly composed of carbohydrate-rich foods (67.91\%), shows a deficiency in 
proteins (5.65\%). Lipid-rich foods cover the remaining 26.44\% of the diet (PNUD/UNOPS, 1998).

\section{MATERIAL AND METHODS}

Heywood (1999) defines non-cultivated plants as: 'plants that grow spontaneously in selfmaintaining populations in natural or semi-natural ecosystems and can exist independently of direct human action'. In accordance with him, we consider as 'wild' all plants that are gathered (not cultivated), even if some of them grow on cultivated rather than on uncultivated or forest land.

\section{Data collection}

All research protocols have been approved and executed in collaboration with University of Kisangani.

Given the lack of reliable information on number and exact location of the Turumbu villages, we opted for a non-probabilistic reasoned sample of 3 research villages (De Pelsmacker and $\&$ Van Kenhove, 2006), with sampling directed by:

1) accessibility (villages in the region are mostly situated along the main road);

2) consisting of 1 tribe (no co-habitation of different tribes because this might influence knowledge and use of WEPs);

3) at least 30 households living in the village;

4) full consent and collaboration of the village chief (and participants) after clear presentation of research objectives and protocols.

Ethnobotanical research was carried out in Yaoseko (August 2007, 00³5’03”N, 02456'14”E, 34 km east of Kisangani, group ‘Yawenda’, 184 households), Yasekwe (September 2007, 00³7’16”N, 024³7’16’E, 61 km east of Kisangani, group 'Yawenda’, 115 
households) and Yalungu (July 2006 and \& September 2007, 046’22”N, 024³2’59”E, 92 km east of Kisangani, group 'Yelongo', 120 households), (figure 1).

An exploratory qualitative approach was used to document all WEPs known at village level and to gain insight in their uses, preparation methods, seasonality patterns and commercialization. According to Rennie and Singh (1996) focus group discussions are claimed to generate results of less apparent precision, but greater evidential value, than more common quantitative survey techniques. The decision to opt for participatory focus group discussions stems from the fact that in an initial phase, with almost no basic ethnobotanical data available, we were interested in an inventory of all WEPs known and used per village/ethnic group, rather than in more in depth individual informants’ knowledge. Focus groups were organized in each village over 5 to 7 days (according to number of WEPs known and in function of the participant's other activities). Each focus group was composed of key informants knowledgeable in plant uses, chosen in collaboration with the village headman (Cotton, 1996) and other, interested villagers. Following Alexiades (1996), the latter were encouraged to participate, because group discussions also serve as social occasions to facilitate transmission of cultural knowledge across generations. The focus group in Yaoseko counted 6 men and 1 women; these totaled 6/2 and 8/2 in Yasekwe and Yalungu, respectively.

During the first session in each village, we asked participants to enumerate all 'wild' plants they know and use as food ('free listing', Cotton, 1996). Plant names were recorded in their

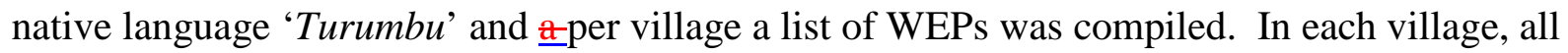
species mentioned on the list were collected during field trips with the key informants ('Walks in the Wood', sensu Alexiades, 1996) to constitute a reference herbarium collection. During subsequent focus group sessions, participants discussed uses, preparation methods, seasonality patterns, commercialization and possible inconveniences for each species on the 
list of WEPs of their village. Discussions were guided by a 'topic list' prepared in advance by the researchers (Cotton, 1996) and answers were recorded upon group consensus.

Finally, in each village, two new groups were formed (men and women apart) for participatory ranking exercises. The men's groups were composed of 5, 4 and 7 participants, the women's groups of 7, 4 and 9 participants for Yaoseko, Yasekwe and Yalungu, respectively. At first, each group had to weigh four characteristics of WEPs: taste, economic value, socio-cultural value and nutritional value; to obtain their relative importance. Weighing was done by distributing 50 palm kernels over the four characteristics, in such a way that the more important a characteristic was according to the group members, the more kernels it was given. Thereafter, researchers asked the group to cite the 10 most important wild fruits. These fruits were subsequently ranked once for each characteristic (adapted from Cotton’s (1996) ‘direct matrix ranking’). Ranking was done by distributing 50 palm kernels over the 10 fruits. In this way, for example,- fruits with a better taste received more kernels than less tastier fruits. This procedure allowed illiterate villagers to take part in the exercise, which was also repeated with 10 wild vegetables.

\section{Data analysis}

\section{Species used as WEP}

Herbarium specimens were identified with the aid of the 'Flore d'Afrique Centrale (CongoKinshasa, Rwanda and \& Burundi)’ (Bamps, 2000 - ) and deposited at the National Botanic Garden of Belgium, Meise (acronym BR). Species names were verified on the IPNI (International Plant Names Index) -website and allocated to botanical families according to the APGII-system.

In what follows, when we refer to vernacular Turumbu names of WEPs, the term 'folkspecies' will be used. When referred to a scientific name, we will use the term 'species'. According 
to Holman (2002), a one-to-one correspondence ( 1 folkspecies = 1 scientific species) may not always be assumed:

1) Bokdam and \& Droogers (1975) found, in the region of Kisangani, that some plants have different vernacular names for different plant parts used (e.g., the fruit may have another name than the whole tree or liana (overdifferentiation));

2) one vernacular name (or folkspecies) may include several scientific species, usually species which are morphologically very similar (underdifferentiation).

\section{Non-food uses of the WEPs}

The number of WEPs having uses in categories other than food was counted. The different use categories were adapted from Cook (1996) to meet field realities of the research area. Secondly, the total number of use citations (one use cited in one village = one use citation), food uses included, were calculated for each plant species (with: total number of use citations $=$ number of use citations in Yalungu + number of use citations in Yasekwe + number of use citations in Yaoseko).

Because non-food uses were not the primary scope of the study, these should be considered as tentative. Only when a WEP figured on the list of WEPs in the respective villages, we asked about other, non-food uses of the species.

\section{Participatory rankings}

The number of kernels a WEP received for a given characteristic was multiplied by the relative importance of the characteristic (i.e., the number of kernels the characteristic obtained during weighing). These results, obtained per WEP for each of the four characteristics, were summed to find the global weighted ranking result of each folkspecies (adapted from Cotton's (1996) 'direct matrix ranking'). 
To obtain an aggregated result for the 6 (= 3 villages $x 2$ groups (men and women)) fruit ranking exercises, the number of times a species appeared in the top three for a given characteristic was counted as well as the number of times a species appeared in the top three of the global weighted ranking. The same procedure was followed for the 6 vegetable rankings.

\section{RESULTS}

\section{Species used}

Table 1 presents the plant species known and used as food in the Turumbu villages studied. 81 folkspecies were identified as 85 scientific species, distributed over 70 genera and $4 \underline{4} 5$ families. Some folkspecies refer to several scientific species. e.g._t the Malvaceae family, for example, comprises 5 Cola-species, but locally these occur as 2 folkspecies- ('Losakanu' is the Turumbu name for Cola bruneelii, C. congolana, C. marsupium and C. urceolata; 'angbongbolia' for C. acuminata). The Apocynaceae family contains most WEPs (7 (folk)species), followed by Malvaceae (6 species, 3 folkspecies), Dioscoreaceae (5 (folk)species) and Araceae, Euphorbiaceae and Fabaceae (each with 4 (folk)species) (table 1).

The number of plants used in all 3 villages, in paired villages and in each simple village is shown in figure 2. Of all plants inventoried, $53 \%$ are used in the 3 villages. Similarities between paired villages vary from $56 \%$ to $73 \%$.

\section{Plant parts used (table 2)}

Most WEPs are used for their fruits (38), followed by leaves (23), seeds (10) and tubers (8). Some WEPs have several plant parts used for food, e.g. fruits of Cola bruneelii are eaten raw, whereas leaves are prepared as leafy vegetables.

\section{Specific food uses}


The 96 plant parts mentioned can be employed raw or prepared as 106 different specific food uses (table 3), with fruit uses being most important, followed by leafy vegetable uses.

\section{Preparation methods}

Leafy vegetables are prepared in 3 different ways. The traditional method consists of wrapping them in leaves of species from the Marantaceae family and to put this package above boiling cassava in the cooking-pot until ready (steaming). Another, similar method is to wrap the vegetables in Marantaceous leaves and put the package close to the fire until done. According to one's own specific taste, salt or chili pepper can be added before consumption. However, the most frequent practice consists of chopping and boiling the vegetables, discarding (or not) the boiling water, adding palm oil, fish or meat, salt, chili pepper or other condiments and let the whole cook.

Seeds of Antrocaryon nannanii, Treculia africana and Panda oleosa are eaten as a snack (nut) or pounded into a paste to season dishes. Seeds of $A$. nannanii are consumed raw; those of $P$. oleosa can be eaten raw or roasted, but need to be roasted before processing them into a paste. Seeds of T. africana are always roasted. The hard shell is removed prior to consumption or preparation into a condiment paste.

Seeds of Tetracarpidium conophorum (conophor nut) are boiled (rarely roasted) to reduce bitterness. When water is drunk within one hour after consumption, one experiences a very bitter sensation in the mouth. the mouth tastes very bitter. Some people claim that the raw nuts are poisonous.

Fruits of Dacryodes osika and Canarium schweinfurthii are dropped in hot, non-boiling water for ten minutes, in a similar way as their cultivated counterpart 'safou,' Dacryodes edulis. 
Young leaves, bark or fruits of Scorodophleus zenkeri and Hua gaboni are used as a substitute for onion and/or garlic. Both species, called 'tropical garlic trees', are highly appreciated by the Turumbu. Leaves of $S$. zenkeri are also prepared as a leafy vegetable.

Roots of Carpolobia alba are chewed either raw or roasted to restore physical forceas of strengthener, for example, during intensive labour.

Seeds of Gilbertiodendron dewevrei are used as a hunger food. Seeds are boiled, peeled and grated into a flour to prepare a paste wrapped in Marantaceous leaves like 'chikwangue' (made of cassava). According the information gathered, their last use dates back to the Simba rebellion in 1964 . With the 1960 war of independence and the following civil wars in Congo, people fled and subsisted on whatever they found in the forest without depending on cultivated plants.

Dioscorea tubers are a good source of dietary starch, but care should be taken before consuming them. Some Dioscorea spp. are extremely poisonous and species are morphologically very similar. Informants warned that tuber -toxicity sometimes depends on the development stage. In Yalungu, for instance, -,informants mentioned -the following for 'elenge' (D. dumetorum): 'When leaves start to dry, the tuber is edible; when leaves are totally dry and start to fall, the tuber is a poison and you will die'.

\section{Seasonality}

Most fruits are available from July till October. Tubers and (leavy) vegetables are available the whole year round (table 1).

\section{Trade}

Although sometimes rather occasionally, almost half of the WEPs known by the Turumbu (47\%) can be sold internally within the village or to passing travellers (table 1). During a 
preliminary market survey, 14 of these species were recorded on the markets of Kisangani (Everaert, 2008).

\section{Non-food uses of WEPs}

Besides being used as food, 64 of the 85 WEPs have one or more other uses: 44 plants have medicinal values; 22 species have uses in the category technology, materials and arts; 19 species have cultural values; 9 species are used as fuels, 8 species for house construction, 5 species as bait, 4 species as fodder, -and 3 species are used as poison (table 4).

The total number of use citations per plant species (food uses included) isare shown in the lastpenultimate -column of table 1. Gilbertiodendron dewevrei and Pentadiplandra brazzeana show the highest number of use citations (15), followed by Anonidium mannii, Clitandra cymulosa, Landolphia owariensis, Costus lucanosianus, Megaphrynium macrostachyum and Piper guineense, each with 12 use citations.

\section{Participatory Ranking}

The aggregated results of the ranking exercises are shown in tables 5 and 6. Only species which appeared more than once in the top three for at least one characteristic are included in the tables.

In the fruit category, Anonidium manni scores best on each characteristic and ranks first in the weighed global ranking. Landolphia owariensis ranks second in the weighed global ranking and scores best (together with A. mannii) on taste and economic value. In the vegetables category, Talinum triangulare scores best on characteristics taste and nutritional value, Megaphrynium macrostachyum on economic and nutritional value, and Hua gaboni on sociocultural value. In the global weighed ranking, $M$. macrostachyum preceeds T. triangulare. 
Surprisingly, the-different ranking exercises with men and women in the same village do not show great differences. Differences seem much higher between villages, although this could not be tested statistically.

Besides their food uses, 'preferred' species have also many other values and can thus be seen as ‘multi-purpose’ species (table 4).

\section{DISCUSSION}

\section{Turumbu WEP knowledge}

Compared to the inventory results of Bokdam and Droogers (1975), Bola and Szafranski (1991), Liengola (2001), Mosango and Isosi (1998), Mosango and Szafranski (1985), Nyakabwa et al. (1990) and Kawukpa and Angoyo (1994), 18 species were cited for the first time as WEP in the region: Celosia leptostachya, Dictyophleba lucida, Landolphia villosa, Raphia sese, Crassocephalum crepidioides, Dioscorea alata, Dioscorea liebrechtsiana, Alchornea cordifolia, Desmodium setigerum, Cola congolana, Penianthus longifolius, Musanga cecropioides, Zanthoxylum macrophyllum, Pancovia laurentii, Bacopa sp., Smilax anceps, Vitex congolensis and Cissus dinklagei.

The single author (Liengola, 2001) who did ethnobotanical research within the 'Collectivité Turumbu', interviewed 31 individual informants and registered 58 WEPs. The present study confirmed the food use of 37 of these species (table 2), whereas 14 species $^{1}$ were not found in our study. For 7 species², identical vernacular names correspond to different scientific species names in our study. Whether this is due to identification differences or underdifferentiation of the local plant classification system, cannot be checked because herbarium references are lacking in Liengola (2001). 
With respect to indigenous knowledge on plant uses, the Turumbu agriculturalists are quite interesting. They know far more WEPs (85) than the Ngandu (69) and Boyela (50) agriculturalists (both Bantous of the Equator Province, DRCongo; Takeda, 1990; Takeda and \& Sato, 1993), and slightly less than the Mbuti (84) or Efe (92) hunter-gatherers (both Pygmies of the Ituri forest, DRCongo; Terashima \&and Ichakawa, 2003). This is surprising, because Pygmies have been the first inhabitants of the Congo basin forest. Based on their closer relationship and longer experience with the forest, one would expect them to know and use a lot more WEPs than the Turumbu, Bantous, who immigrated into the area, only some hundreds of years ago and generally rely more on agriculture for their livelihood. Adding the 14 species Liengola (2001) found to our own 85 WEPs, the Turumbu even seem to know more WEPs than the Mbuti and Efe Pygmies. In addition, the Turumbu exhibit a more uniform pattern of plant use for food than the Pygmies. Terashima and Ichakawa (2003) in their comparative study of 2 Mbuti and 2 Efe communities found similarity values that were always lower than 52\%. Similarity values in our study vary from 56\% to $73 \%$ (figure 2).

\section{Continuum cultivated - non-cultivated plant species}

Focus group discussions revealed some people still gathering Dioscorea tubers in the forest, whilst others have over time domesticated them. In accordance with Leonti et al. (2006), we discovered that distinguishing between cultivated and non-cultivated species is not easy since there exists a continuous spectrum between totally wild and fully domesticated species.

As we are interested in wild foods from the local populations’ point of view, we opted to include Colocasia esculenta and Xanthosoma sagittifolia in our list of wild food plants. Originally introduced as food crops from Asia and tropical America, they became naturalized and omnipresent in wild stands (Safo Kantanka, 2004). Similarly, the fruits of Capsicum frutescens and Solanum aethiopicum are collected both from wild and cultivated stands. 
Including these species in the list is justified since this does not contest the above defined concept of 'wild'.

\section{Continuum foods - medicines}

The difficulty that the Turumbu sometimes have in distinguishing between food and medicinal plants is not surprising. People who traditionally gather wild plants know about additional properties, beneficial for health. For example, Piper guineense fruits are used to season dishes, whereas a decoction from the leaves and/or lianescent stem is consumed with sugar as tea substitute. The same decoction is used to treat general pain, lumbago, cold or cough. Similarly, the decoction of dried Alchornea cordifolia leaves is consumed as a tea substitute and/or as treatment for anaemia. Leonti et al. (2006) already stated that medicine can be food and food can be medicine. It has been documented that different plant parts of the same plant can be used for different purposes, but also that people eat certain foods 'to stay in good health’ (dualism of foods as medicines) (Flyman and $\&$ Afolayan, 2006). Wildgathered vegetables and fruits may, therefore, not only be good supplements to the mainly starchy diets (providing additional proteins, vitamins and minerals), but can also compensate for the lack of pharmacologically active substances, which cultivated species may have lost during domestication (Leonti et al., 2006).

\section{Nutritional potential}

Not all WEPs mentioned to us are consumed on a regular basis (Lykke et al., 2002). Food consumption surveys should therefore indicate which WEPs contribute most to the daily requirements in energy, proteins, lipids, vitamins and minerals. Takeda (1990) observed that only $47.8 \%$ of WEPs known by the Ngandu were regularly consumed. Similarly, the Mbuti use $\epsilon a .100 \underline{84}$ WEPs, but $80 \%$ of their consumption came from just 8 species (Ichikawa, 1993). In some regions, children consume a lot more WEPs than adults (Redzic, 2006). 
Numerous authors stress the high nutritional values of wild foods (e.g. Burlingame, 2000; Ogoye-Ndegwa and \& Aagaard-Hansen, 2003; Keller et al., 2006). For our study area, we may cite the case of the overexploited wild vegetable Gnetum africanum, which is very rich in proteins and minerals (Na, K, Ca, Mg, Fe) and contains all essential amino acids (Okafor, 1995). Herzog et al. (1994) argue that it is not only the high nutrient content, but mainly the fact that wild fruits provide rare nutrients and are an important source of variation and complementation, that make them so important in the African diets. However, wild foods are more and more 'forgotten' and disappear due to social change, urbanization and westernization of African cultures. As a consequence, diets will become more monotonous and deficiencies in nutrients that are now available in adequate amounts may develop (Herzog et al. 1994).

In our own research area, we found -a- lack of information concerning the nutritional values of wild species. With regard to the four locally 'most preferred' species, found only some reliable, but outdated nutritional information was available for waterleaf (Talinum triangulare) in Leung et al. (1968). Matsumoto-Oda and Hayashi (1999) report values on macro-elements in a fruit pulp and seeds mix of Landolphia owariensis, but the Turumbu do not eat seeds, only the pulp of the Landolphia fruits. Although much-consumed and very appreciated, no nutritional data are available for Anondium mannii nor Megaphrynium macrostachyum. On the one hand, providing reliable information about nutritional values of wild plants should help (re)valorize the WEPs and preserve them from being forgotten. On the other hand, less 'healthy' wild foods will be detected. Pteridium aquilinum, for example, which is also consumed by the Turumbu, contains a number of poisonous and antinutritional compounds such as sesquiterpenoids, ecdysone, cyanogenic glycosides, tannins and phenolic acids (van der Burg, 2004). Nutritional analyses of 'promising' species are thus essential before implementing wider programs to promote WEP consumption. 


\section{Commercial potential}

The fruits of Landolphia owariensis, the bark and fruits of Anonidium mannii and the leaves of Megaphrynium macrostachyum (wrapping material) can be found in_Central African markets (Hoare, 2007; Everaert, 2008). Leaves of Marantaceae species traded during 12 months in the Mbandaka market (Equatorial Province, DRCongo) yielded a total value of

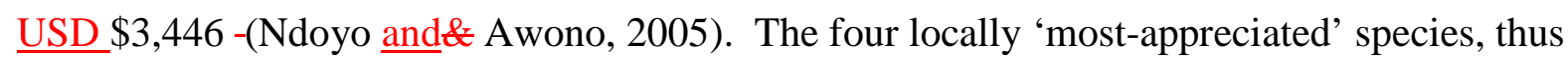
show a certain potential for income generation. Obviously, more research is needed to assess their actual performance and future opportunities in local and regional markets.

Market surveys and value chain analyses should be used to evaluate commercial potential of WEPs (Leakey, 1999). Farmers who are informed about nutritional characteristics, market demand and consumer preferences can make a better informed choice of which wild foods to gather or domesticate/cultivate. In addition, they are able to set their own price for these niche products instead of 'taking' international market prices as for coffee or cocoa. The latter prices, which are far often too low if one cannot rely on the economies of scalescale advantages (Van Damme and $\&$ Termote, 2008). Given the growing interest in new foods, essential oils, pharmaceutical products, etc. in western cultures, some species may also have potential to enterim international markets in the long-term (e.g. the (essential) oils of Canarium schweinfurthii).

Evaluating the nutritional value, the economic potential, cultural preferences and if necessary the pressure on natural resources as a consequence of overexploitation of wild stands of the WEPs will allow for priority setting and thus choosing the right species for participatory domestication and development. There is more and more evidence that participatory domestication of high potential WEPs is a viable strategy to 1) ameliorate nutrition security; 2) increase and diversify farmers’ income; and 3) protect the natural environment from 
overexploitation, thus conserving biodiversity (Leakey, 1999; Leakey et al., 2003;

Tchoundjeu et al., 2006). To provide the incentives to actively plant and manage trees, markets have to be developed and expanded. Clearly, increased dialogue and collaboration between ethnobotanists, agroforestry researchers, food scientists, socio-economists and marketing specialists is necessary to ensure that WEPs can be valorised and (re)adopted.

\section{CONCLUSION}

This study contributes to the understanding of knowledge and use of WEPs by the Turumbu of the Isangi Territory, DRCongo. Focus group discussions -in 3 Turumbu villages resulted in a comprehensive list of 85 WEPs and their different uses. Participatory ranking exercises, mapping preferences in taste, economic, nutritional and cultural values, revealed that the fruits of Anonidium manni and Landolphia owariensis, the unfolded leaves of Megaphrynium macrostachyum and leaves of Talinum triangulare are most appreciated by the Turumbu.

Although we used a qualitative approach, we were able to document 27 WEPs more than Liengola (2001), who used a quantitative approach by interviewing 31 individual informants within the Turumbu community. This confirms the hypothesis that qualitative techniques are especially valuable in regions where basic ethnobotanical data are hardly available and when one is interested in a global overview of plants used for certain finalities, rather than in the mean knowledge of individual informants. Results of qualitative investigations can then further be used in developing tools for quantitative research. However, the fact that Liengola (2001) documented 14 species we could not confirm in our study indicates that even our list is not yet exhaustive: multiplying research sites could add new information.

Besides continued documentation of WEPs and mapping of cultural preferences, there is a huge need for further research on nutritional values of WEPs, dietary patterns and the role of wild foods herein as well as market studies to assess the economic potential and future 
opportunities of these wild foods. -More attention should also be given to studies on the impact of gathering wild plants on the natural environment in the region, to provide sustainable harvest and use options. All these elements will help to set priorities for participatory domestication and further development of the most 'promising' species.

\section{ACKNOWLEDGEMENTS}

The authors thank the Turumbu communities in Yalungu, Yasekwe and Yaoseko for sharing their knowledge and hosting us during field work, and the collaborators at the University of Kisangani and IFA-Yangambi (M. Bwama Meyi, J.-B. Ndjango, P. Musenzi, F. Molimozi and many others) for their assistance during field work. The staff of the herbarium in Meise (Brussels) also deserves a word of thanks. The WEPs Research Project in Tshopo District, executed by University of Ghent in collaboration with University of Kisangani, is financed by the VlIR-UOS (Flemish Inter-University Council, University Development Cooperation; ZEIN2004_3000; MPRDC2007_25).

${ }^{1}$ Dialium polyanthum Harms, Lagenaria siceraria (Molina) Standl., Buchnerodendron speciosum Gürke, Mostuea hirsuta (T.Anderson ex Benth. \& Hook.f.) Baill. ex Baker, Thaumatococcus daniellii (Benn.) Benth. \& Hook.f., Psidium guineense Sw., Blighia welwitschii (Hiern) Radlk., Synsepalum bequaertii De Wild.,

Aframomum angustifolium (Sonn.) K.Schum., Garcinia kola Heckel, Homalium africanum (Hook.f.) Benth., Pentaclethra macrophylla Benth., Heisteria parvifolia Sm., Aframomum melegueta K.Schum.

${ }^{2}$ Crassocephalum sarcobasis (DC.) S.Moore, Pancovia harmsiana Gilg, Cola selengana R.Germ., Urera trinervis (Hochst.) Friis \& Immelman, Amaranthus viridis L., Ancylobotrys amoena Hua and Landolphia jumellei (Pierre ex Jum.) Pichon

\section{REFERENCES}

Alexiades, M. N. (1996). Selected guidelines for Ethnobotanical Research: A Field Manual. New York: The New York Botanical Garden.

Bamps, P. (2000 - ). Flore d'Afrique Centrale (Congo-Kinshasa, Rwanda, Burundi). Meise: Jardin Botanique National de Belgique.

Bokdam, J., and A. F. Droogers (1975). Contribution à l'étude ethnobotanique des Wagenia de Kisangani, Zaïre. Mededelingen Landbouwhogeschool Wageningen - Nederland, 75/19, 174.

Bola, M. L., and F. Szafranski (1991). Plantes spontanées à feuilles-légumes de Kisangani et environs (Zaïre). Belgian Journal of Botany, 124, 222 - 234. 
Burlingame, B. (2000). Wild Nutrition. Journal of Food Composition and Analysis, 13, 99 100.

Chweya, J. A., and P. B. Eyzaguirre (1999). The biodiversity of traditional leafy vegetables. Rome: IPGRI.

Clark, L., S. Asaha, N. Ndam, and P. Blackmore (2004). ERU (Gnetum africanum and G. Buccholzianum). In The Key Non-Timber Forest Products of Central Africa: State of the Knowledge, ed. L. E. Clark and T. C. H. Sunderland, pp. 37-62. USAID: Technical Paper No. 122.

Cook, F. E. M. (1996). Economic Botany Data Collection Standard. Prepared for the International Working Group on Taxonomic Databases for Plant Sciences (TDWG). Kew: Royal Botanic Gardens.

Cotton, C.M. (1996). Ethnobotany. Principles and Applications. Chichester:- John Wiley and Sons Ltd.

De Pelsmacker, P., and P. Van Kenhove (2006). Marktonderzoek: Methoden en toepassingen. Amsterdam: Pearson Education Benelux.

de Saint Moulin, L., and J.-L. T. Kalombo (2005). Atlas de l'organisation administrative de la République Démocratique du Congo. Kinshasa: Centre d'Etudes Pour l'Action Sociale (CEPAS).

Everaert, G. (2008). Toegepast etnobotanisch onderzoek: marktonderzoek over wilde eetbare planten te Kisangani (D.R.Kongo, Oostprovincie). MSc thesis, Ghent University.

FAO (1997). The State of the World's plant genetic resources for Food and Agriculture. Rome: FAO.

Flyman, M. V., and A. J. Afolan (2006). A survey of plants used as wild vegetables in four districts of Bostwana. Ecology of Food and Nutrition, 45, 405-415.

Grivetti, L. E., and B. M. Ogle (2000). Value of traditional foods in meeting macro- and micronutrient needs. The wild plant connection. Nutrition Research Reviews, 13, 31-46.

Herzog, F., Z. Farah and R. Amadò (1994). Composition and consumption of gathered wild fruits in the V-Baoulé, Côté d'Ivoire. Ecology of Food and Nutrition, 32, 181 - 196.

Heywood, V. (1999). Use and potential of wild plants in farm households. FAO Farm Systems Management Series 15. Rome: FAO.

Hoare, A. L. (2007). The use of non-timber forest products in the Congo basin: constraints and opportunities. London: The Rainforest Foundation.

Holman, E. W. (2002). The relation between folk and scientific classifications of plants and animals. Journal of classification, 19, 131 - 159. 
Ichikawa, M. (1993). Diversity and selectivity in the food of the Mbuti hunter-gatherers in Zaire. In Tropical forests, people and food, ed. C. M. Hladik, A. Hladik, O. F. Linares, H. Pagezy, A. Semple and M. Hadley, pp. 487-496. Paris: The Parthenon Publishing Group.

Isangi Territory (2008). Rapport annuel de l'Intérieur exercice 2007 Territoire d'Isangi. Isangi.

Kawukpa, U. U., and M. M. Angoyo (1994). Plantes utiles chez les Batiabetuwa de l'île Mbie, Kisangani, Zaïre. African Study Monographs, 15, 49 - 68.

Keller, G. B., H. Mndiga and B. Maass (2006). Diversity and genetic erosion of traditional vegetables in Tanzania from the farmer's point of view. Plant Genetic Resources, 3, 400-413.

Kienia'h Bikitwa, J. V. (1999). Contribution de l'agriculture paysanne au developpement communautaire des menages agricoles: Cas de la collectivité-Secteur de Turumbu. Kisangani : Mémoire, IFA-Yangambi.

Leakey, R. R. B. (1999). Potential for novel food products form agroforestry trees: a review. Food Chemistry, 66, 1-14.

Leakey, R. R. B., K. Schreckenberg and Z. Tchoundjeu (2003). The participatory domestication of West African Indigenous fruits. International Forestry Review, 5, 338-347.

Leonti, M., S. Nebel, D. Rivera and M. Heinrich (2006). Wild gathered food plants in the European Mediterranean: A comparative analysis. Economic Botany, 60, 130 - 142.

Lester, R. N..2 and A. Seck (2004). Solanum aethiopicum L. In Plant Resources of Tropical Africa 2. Vegetables, ed. G. J. H. Grubben and O. A. Denton, pp. 472-477. Leiden: Blackhuys Publishers.

Leung, W.-T. W., F. Busson and C. Jardin (1968). Food composition table for use in Africa. Rome: FAO.

Liengola, I. B. (2001). Contribution à l'étude des plantes alimentaires spontanées chez les Turumbu et Lokele du district de la Tshopo, Province Orientale, R.D.Congo. Systematics and Geography of Plants, 71, 687 - 698.

Lykke, A. M., O. Mertz and S. Ganaba (2002). Food consumption in rural Burkina Faso. Ecology of Food and Nutrition, 41, 119 - 153.

Malaisse, F., and G. Parent (1985). Edible wild vegetable products in the Zambezian woodland area: a nutritional and ecological approach. Ecology of Food and Nutrition, 18, 4382.

Matsoumoto-Oda, A., and Y. Hayashi (1999). Nutritional aspects of fruit choice by chimpanzees. Folia Primatol, 70, 154-162.

Maundu, P. M. (1996). Utilization and conservation status of wild food plants in Kenya. In The biodiversity of African Plants. Proceedings of the XIV AETFAT Congress. 22-27 August 
1994, Wageningen, The Netherlands, ed. L. J. G. Van der Maesen, X. M. van der Burg and J. M. van Medenbach de Rooy, pp. 678-683. Dordrecht: Kluwer Academic Publishers.

Maundu, P._M. (1997). The status of traditional vegetable utilization in Kenya. In Traditional African Vegetables. Promoting the conservation and use of underutilized and neglected crops. 16. Proceedings of the IPGRI International Workshop on Genetic Resources of Traditional Vegetables in Africa: Conservation and Use, ed. L. Guarino. Rome: International Plant Genetic Resources Institute. http://www.bioversityinternational.org/publications/Web_version/500/begin.htm (Accessed March 16, 2009).

Ministère du plan, République Démocratique du Congo (2005). Monographie de la province Orientale. Kinshasa: Ministère du plan, Unité de Pilotage du Processus DSRP.

Mosango, M., and W. Isosi (1998). Edible plant species used by the human population around Kisangani (Democratic Republic of Congo). Fragmenta Floristica and Geobotanica, 43, 109 - 115.

Mosango, M., and F. Szafranski (1985). Plantes sauvages à fruits comestibles dans les environs de Kisangani (Zaïre). Journal d'Agriculture Traditonnelle et de Botanique Appliquée, 32, 177 - 190.

Ndoye, O., and A. Awono (2005). The Markets Of Non Timber Forest Products In The Provinces of Equateur and Bandundu, Democratic Republic of Congo. CIFOR: Congo Livelihood Improvement and Food Security Project.

Ntamulyango, B. (1975). Analyse économique des associations des cultures chez les paysans Turumbu de Yalibwa (Yangambi). Yangambi : Mémoire, IFA-Yangambi.

Nyakabwa, M., M. Bola- and K. Vasolene (1990). Plantes sauvages alimentaires chez les Kumu de Masako à Kisangani (Zaïre). African Study Monographs, 11, 75 - 86.

Ogoye-Ndegwa, C., and J. Aagaard-Hansen (2003). Traditional gathering of wild vegetables among the Luo of Western Kenya - A nutritional anthropology project. Ecology of Food and Nutrition, 42, 69-89.

Okafor, J.C. (1995). Conservation and use of traditional vegetables from woody forest species in south-eastern Nigeria. In Proceedings of the IPGRI workshop on Genetic Resources of Traditional Vegetables in Africa, August 1995, Nairobi. Nairobi: IPGRI.

PNUD/UNOPS (1998). Monographie de la Province Orientale. Kinshasa: PNUD/UNOPS Programme National de Relance du Secteur Agricole et Rural (PNSAR) 1997-2001.

Prescott-Allen, R., and C. Prescott-Allen (1990). How Many Plants Feed the World? Conservation Biology, 4, 365 - 374.

Redzic, S. J. (2006). Wild Edible Plants and their traditional use in the Human nutrition in Bosnia-Herzegovina. Ecology of Food and Nutrition, 45, 189 - 232. 
Rennie, J. K., and N. C. Singh (1996). Participatory Research for sustainable livelihoods: a guidebook for field projects. London: IISD.

Safo Kantanka, O. (2004). Colocasia esculenta (L.) Schott. In Plant Resources of Tropical Africa 2. Vegetables, ed. G. J. H. Gruben and O. A. Denton, pp. 206 - 211. Leiden:

Blackhuys Publishers.

Shackleton, C., and S. Shackleton, (2004). The importance of Non-timber Forest Products in rural livelihood security and as safety nets: a review of evidence from South-Africa. South African Journal of Science, 100, 658-664.

Takeda, J. (1990). The dietary repertory of the Ngandu people of the tropical rain forest: an ecological and anthropological study of the subsistence activities and food procurement technology of a slash-and-burn agriculturist in the Zaire river basin. African Study Monographs, Suppl. 11, 1-75.

Takeda, J., and H. Sato (1993). Multiple subsistence strategies and protein resources of horticulturalists in the Zaire basin: the Ngandu and the Boyela. In Tropical forests, people and food, ed. C. M. Hladik, A. Hladik, O. F. Linares, H. Pagezy, A. Semple and M. Hadley, pp. 497-504. Paris: The Parthenon Publishing Group.

Tchoundjeu, Z., E. K. Asaah, P. Anegbeh, A. Degrande, P. Mbile, C. Facheux, A. Tsoen, A. R. Atangana, M. L. Ngo-Mpeck and A. J. Simons (2006). Putting participatory domestication into practice in West and Central Africa. Forests, Trees and Livelihoods, 16, 53-69.

Terashima, H., and M. Ichakawa (2003). A comparative Ethnobotany of the Mbuti and Efe Hunter-Gatherers in the Ituri Forest, Democratic Republic of Congo. African Study Monographs, 24, 1-168.

Tshibaka-Mukendi, M.-U. (1975). Etude de l'utilisation du travail chez le planteur du riz dans la localité de Yalibwa (Turumbu). Yangambi: Mémoire, IFA-Yangambi.

The International Plant Names Index. http://www.IPNI.orghttp://www.IPNI.org

UNESCO (2008). MAB Biosphere Reserves Directory. http://www.unesco.org/mabdb/br/brdir/directory/biores.asp?code=ZAI+01\&mode=all (accessed May 18, 2009) consulted: 18 May 2008.

Van Damme, P. (1998). Wild Plants as Food Security in Namibia and Senegal. In The Arid Frontier: Interactive Management of Environment and Development, ed. H. J. Bruins and H. Lithwick, pp. 229-247. Amsterdam: Kluwer Academic Publishers.

Van Damme, P., and C. Termote (2008). African Botanical Heritage for New Crop Development. Afrika Focus, 21, 45 - 64.

van der Burg, W. J. (2004). Pteridium aquilinum (L.) Kuhn. In Plant Resources of Tropical Africa 2. Vegetables, ed. G. J. H. Grubben and O. A. Denton, pp. 439-441. Leiden: Blackhuys Publishers. 
Weinberger, K., and I. Swai (2006). Consumption of traditional vegetables in Central and Northeastern Tanzania. Ecology of Food and Nutrition, 45, 87 - 103.

White, F. (1983). The Vegetation of Africa. A descriptive memory to accompany the UNESCO - AETFAT/UNSO Vegetation map of Africa. UNESCO. 


\section{TABLES AND FIGURES}

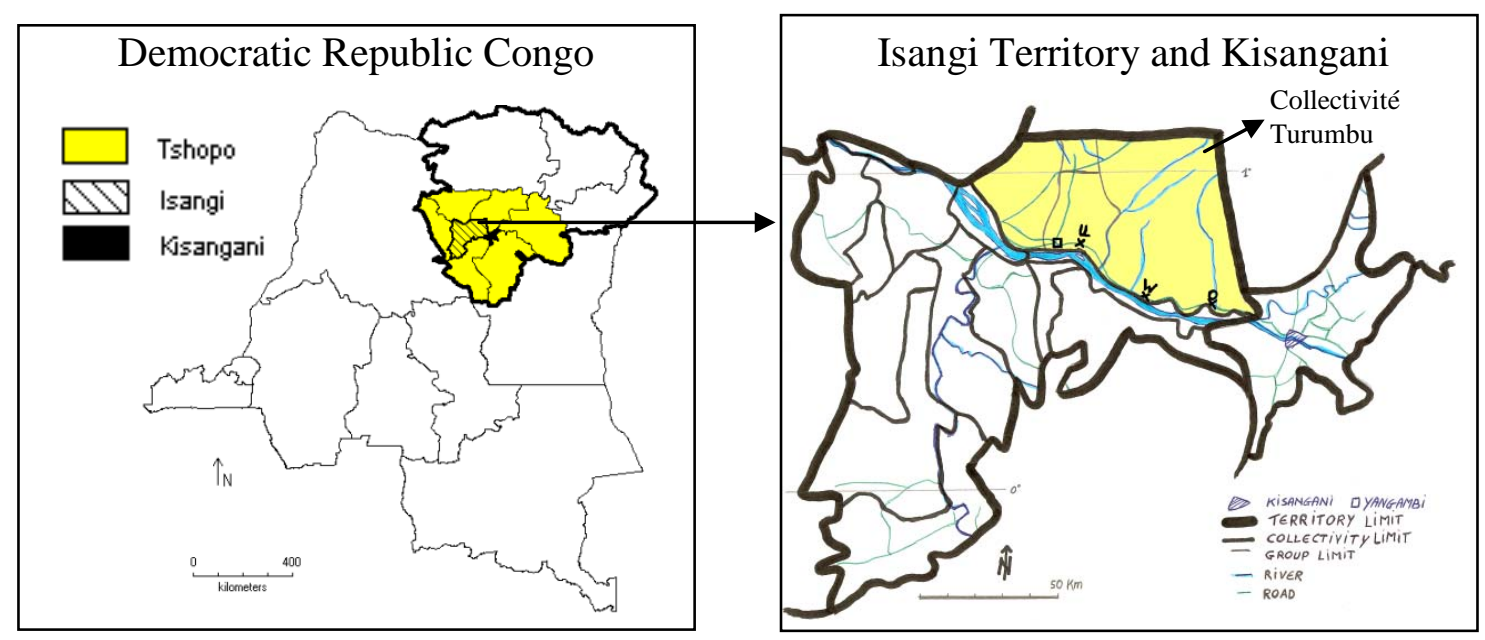


Figure 1: Geographical position of the study area. Left: Tshopo District is one of the four Districts of the Oriental Province and counts 7 territories (Bafwasende, Banalia, Basoko, Isangi, Opala, Ubundu and Yahuma). Right: the 'Collectivité' Turumbu is one of the 13 'Collectivités' of the Isangi Territory. The study villages Yalungu (U), Yasekwe (W) and Yaoseko (O) are indicated on the map.

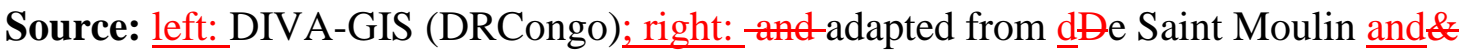
Kalombo-Tshibanda, (2005-(Isangi). 
Table 1: Wild Edible Plants known and used by the Turumbu, Isangi Territory, DRCongo

\begin{tabular}{|c|c|c|c|c|c|c|c|c|c|c|}
\hline Botanical family & Scientific name & Vernacular name $^{1}$ & $\begin{array}{l}\text { Herbarium } \\
\text { reference } \\
\text { (PAS) }^{2}\end{array}$ & $\begin{array}{l}\text { Plant part(s) } \\
\text { used as food }\end{array}$ & $\begin{array}{l}\text { raw or } \\
\text { cooked }^{3}\end{array}$ & Specific use $^{3}$ & Availability & Trade $^{4}$ & $\begin{array}{l}\text { Total number } \\
\text { of uses } \\
\text { citations }^{5}\end{array}$ & $\begin{array}{l}\text { Liengola, } \\
2001\end{array}$ \\
\hline Achariaceae & Caloncoba subtomentosa Gilg & IEisende (o) & 196 & fruit pulp & raw & fruit & NSP 2x/an ${ }^{\circ}$ & & 3 & $\overline{\mathrm{X}}$ \\
\hline \multirow[t]{3}{*}{ Amaranthaceae } & $\begin{array}{l}\text { Amaranthus dubius Mart. ex } \\
\text { Thell. }\end{array}$ & $\begin{array}{l}\text { ngbelengbele (o) } \\
\text { lonenge (w,o) }\end{array}$ & 249, 302 & leaves & cooked & leafy vegetable & permanent & & $\underline{6}$ & \\
\hline & Celosia trigyna L. & iphowuphowu (w,o) & 218 & leaves & cooked & leafy vegetable & permanent & $\mathrm{x}$ & $\underline{2}$ & $\mathrm{X}$ \\
\hline & Celosia leptostachya Benth. & iphowuphowu (w,o) & 1006 & leaves & cooked & leafy vegetable & permanent & $\mathrm{x}$ & $\underline{2}$ & \\
\hline Anacardiaceae & $\begin{array}{l}\text { Antrocaryon nannanii De } \\
\text { Wild. }\end{array}$ & bokongo, kongo (u,w,o) & 993 & seeds & raw & $\begin{array}{l}\text { - nut } \\
\text { - condiment }\end{array}$ & July - Oct. & & (4) & $\mathrm{X}$ \\
\hline Annonaceae & $\begin{array}{l}\text { Anonidium mannii (Oliv.) } \\
\text { Engl. \& Diels }\end{array}$ & anguto $(\mathrm{u}, \mathrm{w}, \mathrm{o})$ & $\begin{array}{l}198,270 \\
316\end{array}$ & fruit pulp & raw & fruit & July - Oct. & $\mathrm{xxx}$ & (12) & $\mathrm{X}$ \\
\hline \multirow[t]{7}{*}{ Apocynaceae } & Clitandra cymulosa Benth. & inono $(\mathrm{u}, \mathrm{w}, \mathrm{o})$ & 263,337 & fruit pulp & raw & fruit & July - Oct. & $\mathrm{xxx}$ & (12) & \\
\hline & $\begin{array}{l}\text { Dictyophleba lucida } \\
\text { (K.Schum.) Pierre }\end{array}$ & $\begin{array}{l}\text { iyoyoliki (u) } \\
\text { liyoliyoliki (w) } \\
\text { iyayawoliki (o) }\end{array}$ & $\begin{array}{l}122,235 \\
997\end{array}$ & fruit pulp & raw & fruit & July - Oct. & $\mathrm{x}$ & (3) & \\
\hline & $\begin{array}{l}\text { Landolphia foretiana (Pierre ex } \\
\text { Jum.) Pichon }\end{array}$ & lingbotoma (o) & 197 & fruit pulp & raw & fruit & July - Oct. & & 3 & \\
\hline & $\begin{array}{l}\text { Landolphia owariensis } \\
\text { P.Beauv. }\end{array}$ & $\begin{array}{l}\text { lilolo (u) } \\
\text { liyo }(\mathrm{w}, \mathrm{o})\end{array}$ & $\begin{array}{l}336,984 \\
228,272\end{array}$ & fruit pulp & raw & fruit & July - Oct. & $\mathrm{xxx}$ & (12) & $\mathrm{X}$ \\
\hline & Landolphia villosa J.G.M.Pers. & $\begin{array}{l}\text { libii (u) } \\
\text { lilombo (w) Inono (w) }\end{array}$ & 293, 1001 & fruit pulp & raw & fruit & July - Oct. & $\mathrm{xx}$ & $\underline{5}$ & \\
\hline & Landolphia sp1 & ngilaseka (u,w) & 327 & fruit pulp & raw & fruit & July - Oct. & $\mathrm{x}$ & $\underline{5}$ & \\
\hline & $\begin{array}{l}\text { Saba comorensis (Bojer ex } \\
\text { A.DC.) Pichon }\end{array}$ & $\begin{array}{l}\text { lilombo }(u, o) \\
\text { libii }(w)\end{array}$ & $\begin{array}{l}240 \\
303\end{array}$ & fruit pulp & raw & fruit & July - Oct. & $\mathrm{xx}$ & (5) & \\
\hline \multirow[t]{3}{*}{ Araceae } & Anchomanes giganteus Engl. & likondoyaolimo (o) & 222 & young sprouts & cooked & vegetable & permanent & & 1 & \\
\hline & Colocasia esculenta (L.) Schott & maniango (o) & & tubers & cooked & starch & permanent & $\mathrm{x}$ & 1 & \\
\hline & $\begin{array}{l}\text { Xanthosoma sagittifolium (L.) } \\
\text { Schott }\end{array}$ & yopho (o) & & $\begin{array}{l}\text { - tubers } \\
\text { - leaves }\end{array}$ & $\begin{array}{l}\text { cooked } \\
\text { cooked }\end{array}$ & $\begin{array}{l}\text { starch } \\
\text { leafy vegetable }\end{array}$ & permanent & $\mathrm{x}$ & 2 & \\
\hline
\end{tabular}




\begin{tabular}{|c|c|c|c|c|c|c|c|c|c|c|}
\hline \multirow[t]{2}{*}{ Arecaceae } & $\begin{array}{l}\text { Laccosperma secundiflorum } \\
\text { (P.Beauv.) Kuntze }\end{array}$ & (boloke bo) Likawu (u,o) & 229, 319 & leaf button & cooked & vegetable & permanent & & $\underline{8}$ & $\mathrm{X}$ \\
\hline & Raphia sese De Wild. & ikolo, fande (u) & 312 & $\begin{array}{l}\text { - fruit pulp } \\
\text { - tree sap }\end{array}$ & $\begin{array}{l}\text { cooked } \\
\text { raw }\end{array}$ & $\begin{array}{l}\text { fruit } \\
\text { beverage (palm wine) }\end{array}$ & permanent & & 6 & \\
\hline Asteraceae & $\begin{array}{l}\text { Crassocephalum crepidioides } \\
\text { (Benth.) S.Moore }\end{array}$ & limbiti (u,w,o) & 20,332 & leaves & cooked & leafy vegetable & permanent & $\mathrm{x}$ & (4) & \\
\hline \multirow[t]{2}{*}{ Burseraceae } & Canarium schweinfurthii Engl. & bobele, ibele $(\mathrm{u}, \mathrm{w}, \mathrm{o})$ & 232 & fruit pulp \& skin & cooked & fruit & July - Oct. & $\mathrm{xx}$ & (9) & $\mathrm{X}$ \\
\hline & $\begin{array}{l}\text { Dacryodes osika (Guillaumin) } \\
\text { H.J.Lam. }\end{array}$ & $\begin{array}{l}\text { ibele sawu, isawusawu } \\
(\mathrm{u}, \mathrm{w}, \mathrm{o})\end{array}$ & 239 & fruit pulp \& skin & $\begin{array}{l}\text { - cooked } \\
\text { - roasted }\end{array}$ & $\begin{array}{l}\text { fruit } \\
\text { fruit }\end{array}$ & July - Oct. & $\mathrm{xx}$ & (5) & \\
\hline Clusiaceae & Mammea africana Sabine & boliti (o) & 244 & fruit pulp & raw & fruit & July - Oct. & & 2 & $\mathrm{X}$ \\
\hline Costaceae & $\begin{array}{l}\text { Costus lucanusianus J.Braun \& } \\
\text { K.Schum. }\end{array}$ & bokako (bobaye) (u,w,o) & $\begin{array}{l}13,224,266, \\
309\end{array}$ & $\begin{array}{l}\text { - stem } \\
\text { - flower }\end{array}$ & $\begin{array}{l}\text { raw } \\
\text { raw }\end{array}$ & $\begin{array}{l}\text { fruit } \\
\text { fruit }\end{array}$ & $\begin{array}{l}\text { permanent } \\
\text { July - Oct. }\end{array}$ & & (12) & $\mathrm{X}$ \\
\hline $\begin{array}{l}\text { Dennsteadtiaceae } \\
\text { (pteridophyta) }\end{array}$ & Pteridium aquilinum (L.) Kuhn & lilele (o) & 205 & immature fronds & cooked & condiment & permanent & & 4 & \\
\hline Dichapetalaceae & $\begin{array}{l}\text { Dichapetalum mombuttense } \\
\text { Engl. }\end{array}$ & $\begin{array}{l}\text { ekpalanganga }(\mathrm{u}, \mathrm{o}) \\
\text { lisungulingba/lisunguliteti } \\
(\mathrm{w}, \mathrm{o})\end{array}$ & $\begin{array}{l}11,17,311 \\
211,267\end{array}$ & fruit pulp & raw & fruit & permanent & & (5) & $\mathrm{X}$ \\
\hline \multirow[t]{5}{*}{ Dioscoreaceae } & Dioscorea alata L. & $\begin{array}{l}\text { ltEengu (o) } \\
\text { illumbelumbe (w) }\end{array}$ & 243 & tubers & cooked & starch & permanent & $\mathrm{xx}$ & $\underline{2}$ & \\
\hline & Dioscorea baya De Wild. & ịłkuse $(u, w, o)$ & 989,1000 & tubers & cooked & starch & permanent & $\mathrm{xx}$ & (3) & \\
\hline & $\begin{array}{l}\text { Dioscorea dumetorum (Kunth) } \\
\text { Pax }\end{array}$ & $\begin{array}{l}\text { eElenge (u) } \\
\text { yYayii (w,o) }\end{array}$ & $\begin{array}{l}119 \\
290\end{array}$ & tubers & cooked & starch & permanent & $\mathrm{xxx}$ & (3) & \\
\hline & $\begin{array}{l}\text { Dioscorea liebrechtsiana De } \\
\text { Wild. \& T.Durand }\end{array}$ & bBBosondi (u,w,o) & $\begin{array}{l}330,996 \\
1004\end{array}$ & tubers & cooked & starch & permanent & $\mathrm{xxx}$ & (3) & \\
\hline & Dioscorea minutiflora Engl. & ịkeke (u,w,o) & $\begin{array}{l}18,121,216 \\
277,310 \\
987,999\end{array}$ & tubers & cooked & starch & permanent & $\mathrm{xx}$ & (3) & \\
\hline \multirow[t]{2}{*}{ Euphorbiaceae } & $\begin{array}{l}\text { Alchornea cordifolia } \\
\text { (Schumach. \& Thonn.) } \\
\text { Müll.Arg. }\end{array}$ & liondje (u,w,o) & $\begin{array}{l}16,23,213 \\
297\end{array}$ & dry leaves & cooked & decoction (tea subst.) & permanent & & (9) & \\
\hline & $\begin{array}{l}\text { Erythrococca atrovirens (Pax) } \\
\text { Prain var. flaccida (Pax) }\end{array}$ & likile $(w, o)$ & 241 & leaves & cooked & leafy vegetable & permanent & & $\underline{5}$ & \\
\hline
\end{tabular}




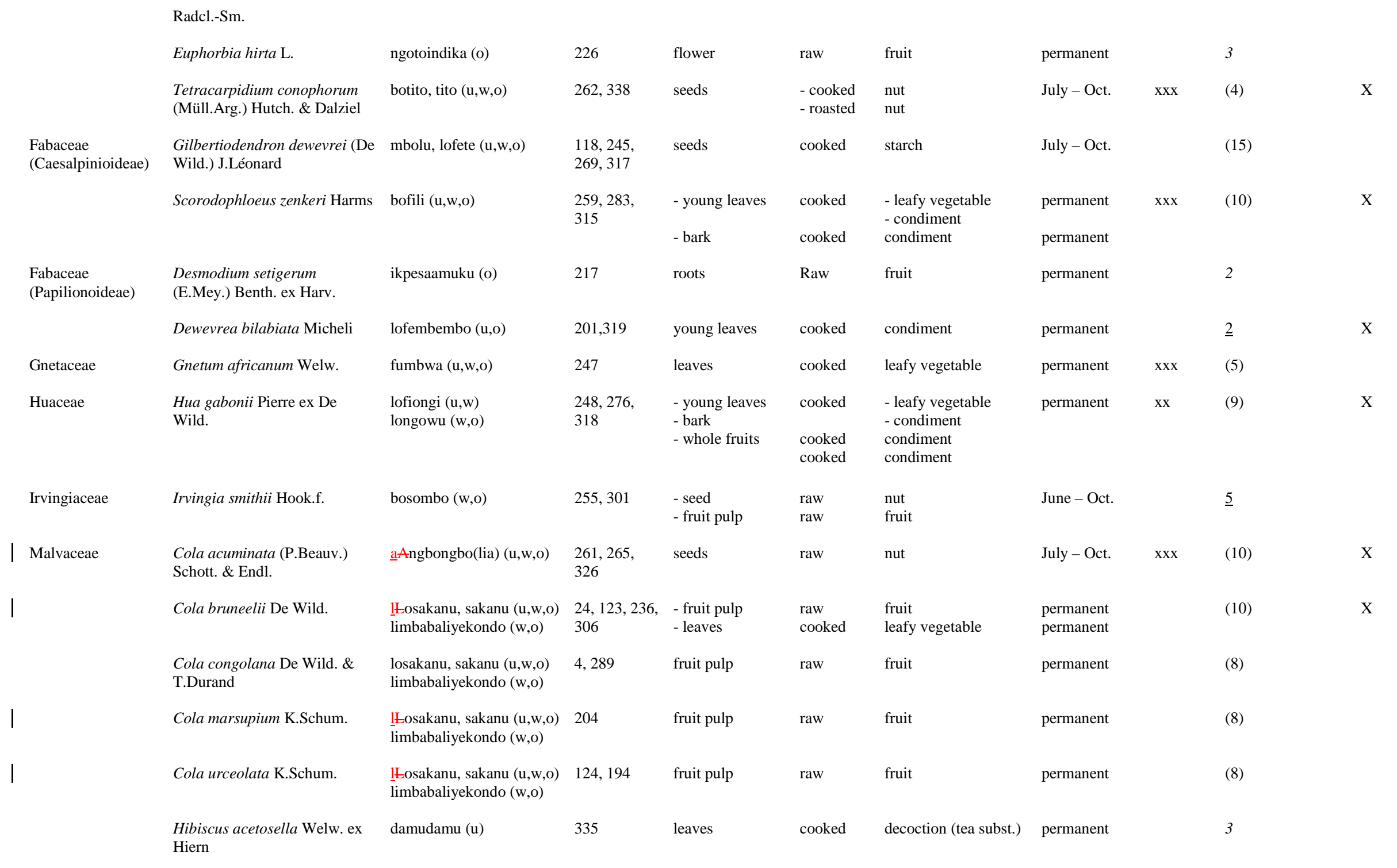




\begin{tabular}{|c|c|c|c|c|c|c|c|c|c|c|}
\hline \multirow[t]{3}{*}{ Marantaceae } & $\begin{array}{l}\text { Megaphrynium macrostachyum } \\
\text { (Benth.) Milne-Redh. }\end{array}$ & $\begin{array}{l}\text { (bolokebo)likongo, beye } \\
(\mathrm{u}, \mathrm{w}, \mathrm{o})\end{array}$ & $\begin{array}{l}237,275 \\
323\end{array}$ & leaf buds & cooked & vegetable & permanent & $\mathrm{xx}$ & (12) & $\mathrm{X}$ \\
\hline & $\begin{array}{l}\text { Trachyphrynium braunianum } \\
\text { (K.-Schum.) Baker }\end{array}$ & $\begin{array}{l}\text { ikokombeshalia, } \\
\text { bolikabwalima (w) }\end{array}$ & 281 & seeds & raw & fruit & permanent & & $\underline{4}$ & \\
\hline & & ikokombeibaye (o) & 223 & & & & & & & \\
\hline Melastomataceae & $\begin{array}{l}\text { Tristemma mauritianum } \\
\text { J.F.Gmel. }\end{array}$ & lituma lilokonda $(\mathrm{u}, \mathrm{w}, \mathrm{o})$ & 1, 214, 286 & whole fruit & raw & fruit & permanent & & (6) & $\mathrm{X}$ \\
\hline \multirow[t]{2}{*}{ Menispermaceae } & $\begin{array}{l}\text { Chasmanthera welwitschii } \\
\text { Troupin }\end{array}$ & $\begin{array}{l}\text { ndénde (u) } \\
\text { tongatobolondi (w) }\end{array}$ & 331 & fruit pulp \& skin & raw & fruit & June - Sept. & & $\underline{2}$ & $\mathrm{X}$ \\
\hline & Penianthus longifolius Miers & İokumbo (o) & 200 & fruit pulp & raw & fruit & permanent & & 4 & \\
\hline \multirow[t]{2}{*}{ Moraceae } & $\begin{array}{l}\text { Musanga cecropioides R.Br. ex } \\
\text { Tedlie }\end{array}$ & Bbibokombo (o) & 221 & young sprouts & cooked & vegetable & permanent & & 3 & \\
\hline & $\begin{array}{l}\text { Treculia africana Decne. ssp. } \\
\text { africana var. africana }\end{array}$ & $\begin{array}{l}\frac{\mathrm{b} B o m b i m b o}{(\mathrm{u}, \mathrm{w}, \mathrm{o})} \\
\text { limbimbo }\end{array}$ & $\begin{array}{l}203,296 \\
325\end{array}$ & seeds & roasted & $\begin{array}{l}\text { - nut } \\
\text { - condiment }\end{array}$ & permanent & & (3) & $\mathrm{X}$ \\
\hline Pandaceae & Panda oleosa Pierre & bakale (u,w,o) & 2, 199, 285 & seeds & $\begin{array}{l}\text { - raw } \\
\text { - roasted }\end{array}$ & $\begin{array}{l}\text { nut } \\
\text { - nut } \\
\text { - condiment }\end{array}$ & permanent $^{\dagger}$ & $\mathrm{xx}$ & (5) & $\mathrm{X}$ \\
\hline Passifloraceae & Passiflora foetida $\mathrm{L}$. & maveve (u,w,o) & $\begin{array}{l}225,292 \\
314\end{array}$ & $\begin{array}{l}\text { fruit pulp \& } \\
\text { seeds }\end{array}$ & raw & fruit & permanent & & (4) & $\mathrm{X}$ \\
\hline Pentadiplandraceae & $\begin{array}{l}\text { Pentadiplandra brazzeana } \\
\text { Baill. }\end{array}$ & $\begin{array}{l}\text { etekele, amelalokulu } \\
\text { (u,w,o) }\end{array}$ & $\begin{array}{l}210,282 \\
307\end{array}$ & fruit pulp & raw & fruit & permanent & $\mathrm{xxx}^{\ddagger}$ & (15) & $\mathrm{X}$ \\
\hline Phyllantaceae & Hymenocardia ulmoides Oliv. & bokelele $(w, 0)$ & 227,280 & young leaves & cooked & decoction (tea subst.) & permanent & & $\underline{8}$ & \\
\hline \multirow[t]{2}{*}{ Phytolaccaceae } & $\begin{array}{l}\text { Hilleria latifolia (Lam.) } \\
\text { H.Walter }\end{array}$ & lokobo $(\mathrm{u}, \mathrm{w}, \mathrm{o})$ & $\begin{array}{l}14,256,300, \\
333\end{array}$ & leaves & cooked & leafy vegetable & permanent & & (6) & $\mathrm{X}$ \\
\hline & Phytolacca dodecandra L'Hér. & lisingo (u,w,o) & 322 & leaves & cooked & leafy vegetable & permanent & & (4) & $\mathrm{X}$ \\
\hline \multirow[t]{2}{*}{ Piperaceae } & $\begin{array}{l}\text { Peperomia pellucida (L.) } \\
\text { Kunth }\end{array}$ & lombaye lolitoko (u) & 120 & leaves & cooked & leafy vegetable & permanent & & 1 & \\
\hline & $\begin{array}{l}\text { Piper guineense Schumach. \& } \\
\text { Thonn. }\end{array}$ & iketu $(\mathrm{u}, \mathrm{w}, \mathrm{o})$ & $\begin{array}{l}19,233,273, \\
321\end{array}$ & $\begin{array}{l}\text { - leaves } \\
\text { - liana } \\
\text { - whole fruits }\end{array}$ & $\begin{array}{l}\text { cooked } \\
\text { cooked } \\
\text { raw }\end{array}$ & $\begin{array}{l}\text { decoction (tea subst.) } \\
\text { decoction (tea subst.) } \\
\text { condiment }\end{array}$ & $\begin{array}{l}\text { permanent } \\
\text { permanent } \\
\text { July - Jan. }\end{array}$ & $\mathrm{xxx}$ & (12) & $\mathrm{X}$ \\
\hline Plantaginaceae & Васора sp. & ingawungawu (w) & 295, 995 & leaves & cooked & decoction (tea subst.) & permanent & & 1 & \\
\hline
\end{tabular}




\begin{tabular}{|c|c|c|c|c|c|c|c|c|c|c|}
\hline Polygalaceae & Carpolobia alba G.Don & lokembia (w,o) & 288 & roots & $\begin{array}{l}\text { - raw } \\
\text { - roasted }\end{array}$ & $\begin{array}{l}\text { strenghtener } \\
\text { strenghtener }\end{array}$ & permanent & $\mathrm{xx}$ & $\underline{3 z}$ & $\mathrm{X}$ \\
\hline Portulacaceae & $\begin{array}{l}\text { Talinum triangulare (Jacq.) } \\
\text { Willd. }\end{array}$ & $\begin{array}{l}\text { melelu (u) } \\
\text { sese (w,o) }\end{array}$ & $\begin{array}{l}8,313 \\
219,299\end{array}$ & leaves & cooked & leafy vegetable & permanent & $\mathrm{x}$ & (5) & $\mathrm{X}$ \\
\hline \multirow[t]{2}{*}{ Rubiaceae } & $\begin{array}{l}\text { Sabicea johnstonii K.Schum. } \\
\text { ex Wernham }\end{array}$ & damudamu (o) & 230 & whole fruit & raw & fruit & permanent & & 2 & \\
\hline & $\begin{array}{l}\text { Sherbournia bignoniiflora } \\
\text { (Welw.) Hua }\end{array}$ & lॄosabola $(\mathrm{u}, \mathrm{w}, \mathrm{o})$ & $\begin{array}{l}\text { 6, 212, 264, } \\
305\end{array}$ & $\begin{array}{l}\text { - fruit pulp \& } \\
\text { seeds } \\
\text { - leaves }\end{array}$ & $\begin{array}{l}\text { raw } \\
\text { cooked }\end{array}$ & $\begin{array}{l}\text { fruit } \\
\text { decoction (tea subst.) }\end{array}$ & $\begin{array}{l}\text { permanent } \\
\text { permanent }\end{array}$ & & (7) & $\mathrm{X}$ \\
\hline Rutaceae & $\begin{array}{l}\text { Zanthoxylum macrophyllum } \\
\text { Nutt. var preussii Engl. }\end{array}$ & bBBolongo (o) & 258 & bark & cooked & decoction (tea subst.) & permanent & & 5 & \\
\hline \multirow[t]{2}{*}{ Sapindaceae } & $\begin{array}{l}\text { Chytranthus macrobotrys } \\
\text { (Gilg) Exell \& Mendonça }\end{array}$ & botokolo, tokolo (u,w,o) & 246, 329 & seeds & cooked & nut & July - Oct. & $\mathrm{x}$ & (3) & \\
\hline & $\begin{array}{l}\text { Pancovia laurentii (De Wild.) } \\
\text { Gilg ex De Wild. }\end{array}$ & botende, ntende (u,w,o) & 260,1002 & fruit pulp & raw & fruit & July - Oct. & $\mathrm{x}$ & (5) & \\
\hline \multirow[t]{3}{*}{ Sapotaceae } & $\begin{array}{l}\text { Chrysophyllum lacourtianum } \\
\text { De Wild. }\end{array}$ & bolinda, lilinda $(\mathrm{u}, \mathrm{w}, \mathrm{o})$ & $\begin{array}{l}207,291 \\
334\end{array}$ & fruit pulp & raw & fruit & July - Oct. & $\mathrm{xxx}$ & (6) & $\mathrm{X}$ \\
\hline & $\begin{array}{l}\text { Synsepalum brevipes (Baker) } \\
\text { T.D.Penn. }\end{array}$ & bokokolo, ikokolo (w,o) & 254 & fruit pulp & raw & fruit & June - Aug. & $\mathrm{xx}$ & $\underline{3}$ & $\mathrm{X}$ \\
\hline & $\begin{array}{l}\text { Synsepalum stipulatum } \\
\text { (Radlk.) Engl. }\end{array}$ & bonga, tonga $(\mathrm{u}, \mathrm{w}, \mathrm{o})$ & $\begin{array}{l}9,21,251 \\
287,324\end{array}$ & fruit pulp & raw & fruit & April - July & $\mathrm{xxx}$ & (4) & $\mathrm{X}$ \\
\hline Smilacaceae & Smilax anceps Willd. & likako $(u, w, o)$ & $\begin{array}{l}252,988 \\
1005\end{array}$ & tubers & cooked & starch & permanent & $\mathrm{xx}$ & (4) & \\
\hline \multirow[t]{3}{*}{ Solanaceae } & Capsicum frutescens L. & mMbase ikukunde $(w, o)$ & 220,274 & whole fruit & raw & condiment & permanent & $\mathrm{xx}$ & $\underline{7}$ & $\mathrm{X}$ \\
\hline & $\begin{array}{l}\text { Solanum distichum Schumach. } \\
\text { \& Thonn." }\end{array}$ & îkalu $(w, 0)$ & $\begin{array}{l}206,278 \\
992\end{array}$ & fruit juice & cooked & decoction (tea subst.) & permanent & & $\underline{2}$ & \\
\hline & $\begin{array}{l}\text { Solanum aethiopicum L. } \\
\text { "gilo group" }\end{array}$ & l_tosuke $(\mathrm{w}, \mathrm{o})$ & 994 & whole fruit & cooked & $\begin{array}{l}\text { - vegetable } \\
\text { - condiment }\end{array}$ & $\begin{array}{l}\text { permanent } \\
\text { permanent }\end{array}$ & $\mathrm{x}$ & $\underline{5}$ & $\mathrm{X}$ \\
\hline Tiliaceae & $\begin{array}{l}\text { Desplatsia dewevrei (De Wild. } \\
\text { \& T.Durand) Burret }\end{array}$ & $\begin{array}{l}\text { bokomba, likamba (u) } \\
\text { lisuli (w,o) }\end{array}$ & 257,271 & seeds & raw & nut & permanent & & (8) & $\mathrm{X}$ \\
\hline Urticaceae & Myrianthus arboreus P.Beauv. & $\begin{array}{l}\text { bongunguna (u) } \\
\text { bohuma }(\mathrm{w}, \mathrm{o})\end{array}$ & $\begin{array}{l}304 \\
209,298\end{array}$ & fruit pulp & raw & fruit & July - Oct. & $\mathrm{xx}$ & (6) & $\mathrm{X}$ \\
\hline
\end{tabular}


Vitaceae

Cissus dinklagei Gilg \& $\quad$ wese (o)

M.Brandt

Cyphostemma adenocaule (Steud. ex A.Rich.) Desc. ex

(u), (w) and (o) vernacular name(s) under which the plant species is known and used in Yalungu, Yasekwe and Yaoseko, respectively.

All vernacular names have their corresponding plurals by changing the prefixes, e.g. 'ikeke' becomes 'tokeke', 'liyo' becomes 'ayo', etc.

${ }^{2}$ Vouchers are stored under the reference: PAS followed by the respective numbers; PAS 1 - 25, PAS 118 - 124, PAS 304 - 338 and PAS 984 - 985 have been collected by the first author in Yalungu; PAS 264 - 303 and PAS 986 - 996 have been collected by the first author in Yasekwe; PAS 194 - 263 and PAS 997 - 1007 have been collected by the first author in Yaoseko

${ }^{3}$ When more than 1 plant part is used per plant species, they are separated with dashes, idem for more than one preparation method per plant part used and more than one specific use per preparation method. ${ }^{4} \mathrm{x}=$ species traded in 1 village, $\mathrm{xx}=$ species traded in 2 villages, $\mathrm{xxx}=$ species traded in the 3 villages

${ }^{5}$ numbers in between brackets: total number of uses cited in the 3 villages; numbers underlined: total number of uses cited in the 2 villages where the species has at least one food use; numbers in italic: total number of uses cited in the only village where the species has at least one food use. The numbers into brackets can only be compared with other numbers into brackets. Idem for the numbers underlined and those in italic.

- Period not known by the focus group members, but appears two times a year

${ }^{\dagger}$ Fruits mature between June and Oct., they putrefy the whole year round on the ground and can be gathered at any time of the year. The more the fruit flesh is rot, the easier the access to the kernel.

${ }^{*}$ It are not the edible fruits of Pentadiplandra brazzeana that are commercialized, but the roots for medicinal purposes.

" The non-prickly semi-domesticated Solanum distichum may well be treated as a cultivar-group of the prickly wild progenitor Solanum anguivi Lam.(Lester \& Seck, 2004). 


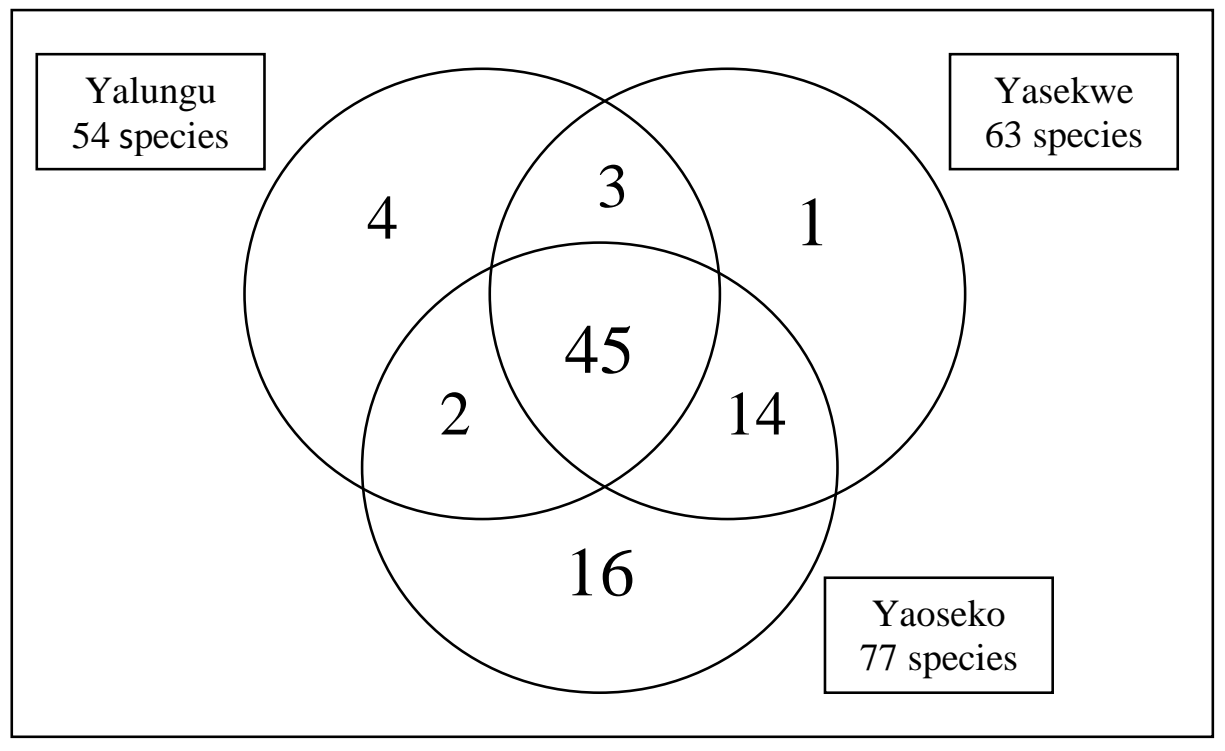


Figure 2: Number of WEP-species used in all three Turumbu villages surveyed (inner circle), and in only two or one village (outer circle segments); behind each village name, the total number of species identified in this village is given. 
Table 2: WEP-parts used by the Turumbu, Isangi Territory, DRCongo

\begin{tabular}{lc}
\hline Plant parts used & Number of plants \\
\hline fruits & 38 \\
leaves & 23 \\
seeds & 10 \\
tubers & 8 \\
stem \& stem sap & 4 \\
bsark & 3 \\
leaf buds & 2 \\
young sprouts & 2 \\
flowers & 2 \\
roots & 2 \\
immature fronds & 1 \\
whole plant & 1 \\
\hline TOTAL & $\mathbf{9 6}$ \\
\hline
\end{tabular}

Table 3: Specific uses of the WEPs used by the Turumbu, Isangi Territory, DRCongo

\begin{tabular}{lc}
\hline Specific use & Number of plants \\
\hline fruit & 39 \\
leafy vegetables & 15 \\
condiment & 13 \\
tea substitute & 11 \\
nut & 10 \\
starch & 9 \\
other vegetables & 5 \\
strenghtener & 2 \\
water substitute & 1 \\
palm wine & 1 \\
\hline TOTAL & $\mathbf{1 0 6}$
\end{tabular}


Table 4: Non-food uses of the WEPs used by the Turumbu, Isangi Territory, DRCongo

\begin{tabular}{|c|c|c|c|c|}
\hline Botanical family & Scientific name & Vernacular name $^{1}$ & $\begin{array}{l}\text { Use } \\
\text { category }\end{array}$ & Specific use $^{2}$ \\
\hline Achariaceae & Caloncoba subtomentosa Gilg & lEisende (o) & $\begin{array}{l}\text { construction } \\
\text { fodder }\end{array}$ & $\begin{array}{l}\text { branches: sticks for houses (o) } \\
\text { host tree for edible caterpillars (o) }\end{array}$ \\
\hline Amaranthaceae & $\begin{array}{l}\text { Amaranthus dubius- Mart. ex } \\
\text { Thell. }\end{array}$ & $\begin{array}{l}\text { ngbelengbele }(0) \\
\text { lonenge }(\mathrm{w}, 0)\end{array}$ & $\begin{array}{l}\text { fodder } \\
\text { cultural }\end{array}$ & $\begin{array}{l}\text { porc feed (o) } \\
\text { leaves: chasing bad spirits/witches (o,w) } \\
\text { leaves: ancestral benediction (o) }\end{array}$ \\
\hline Anacardiaceae & Antrocaryon nannanii De Wild. & $\begin{array}{l}\text { bokongo, kongo } \\
(\mathrm{u}, \mathrm{w}, \mathrm{o})\end{array}$ & fuels & firewood (w) \\
\hline Annonaceae & $\begin{array}{l}\text { Anonidium mannii (Oliv.) Engl. } \\
\text { \& Diels }\end{array}$ & anguto $(\mathrm{u}, \mathrm{w}, \mathrm{o})$ & $\begin{array}{l}\text { medicinal } \\
\text { cultural }\end{array}$ & $\begin{array}{l}\text { bark: serpent bite }(\mathrm{o}, \mathrm{u}) \text {, eye injuriy }(\mathrm{o}) \text {, foot } \\
\text { wounds }(\mathrm{o}, \mathrm{u}) \text {, stop bleeding and pain after } \\
\text { childbirth }(\mathrm{w}, \mathrm{u}) \text {, lumbago (u) } \\
\text { bark: ancestral judgement of guilt (u) }\end{array}$ \\
\hline \multirow[t]{6}{*}{ Apocynaceae } & Clitandra cymulosa Benth. & inono $(\mathrm{u}, \mathrm{w}, \mathrm{o})$ & $\begin{array}{l}\text { tech \& } \text { mat }^{\underline{3}} \\
\text { medicinal } \\
\text { bait }\end{array}$ & $\begin{array}{l}\text { latex: making balls }(\mathrm{o}, \mathrm{u}, \mathrm{w}) \text {, ngong sticks }(\mathrm{o}) \text {, } \\
\text { repair flat tyres }(\mathrm{o}, \mathrm{u}, \mathrm{w}) \\
\text { latex: intestinal worms (o) } \\
\text { apes feed in traps (u) }\end{array}$ \\
\hline & $\begin{array}{l}\text { Landolphia foretiana (Pierre ex } \\
\text { Jum.) Pichon }\end{array}$ & lingbotoma (o) & tech \& mat & latex: making balls (o), repair flat tyres (o) \\
\hline & Landolphia owariensis P.Beauv. & $\begin{array}{l}\text { lilolo }(\mathrm{u}) \\
\text { liyo }(\mathrm{w}, \mathrm{o})\end{array}$ & $\begin{array}{l}\text { tech \& mat } \\
\text { bait }\end{array}$ & $\begin{array}{l}\text { latex: for making balls }(\mathrm{o}, \mathrm{w}, \mathrm{u}) \text {, ngong sticks } \\
(\mathrm{o}, \mathrm{w}) \text {, repair flat tyres }(\mathrm{o}, \mathrm{w}, \mathrm{u}) \\
\text { apes feed in traps }(\mathrm{u})\end{array}$ \\
\hline & Landolphia villosa J.G.M.Pers. & $\begin{array}{l}\text { libii (u) } \\
\text { lilombo (w) Inono } \\
\text { (w) }\end{array}$ & $\begin{array}{l}\text { tech \& mat } \\
\text { bait } \\
\text { bait }\end{array}$ & $\begin{array}{l}\text { latex: making balls }(\mathrm{u}) \text {, repair flat tyres }(\mathrm{u}) \\
\text { apes feed in traps }(\mathrm{u})\end{array}$ \\
\hline & Landolphia sp1 & ngilaseka $(\mathrm{u}, \mathrm{w})$ & $\begin{array}{l}\text { tech \& mat } \\
\text { bait }\end{array}$ & $\begin{array}{l}\text { latex: making balls (w), repair flat tyres (w) } \\
\text { apes feed in traps }\end{array}$ \\
\hline & $\begin{array}{l}\text { Saba comorensis (Bojer ex } \\
\text { A.DC.) Pichon }\end{array}$ & $\begin{array}{l}\text { lilombo }(u, o) \\
\text { libii }(w)\end{array}$ & medicinal & $\begin{array}{l}\text { roots: gonorrhoea (o) } \\
\text { fruit juice: haemorrhoids (o) }\end{array}$ \\
\hline \multirow[t]{2}{*}{ Arecaceae } & $\begin{array}{l}\text { Laccosperma secundiflorum } \\
\text { (P.Beauv.) Kuntze }\end{array}$ & $\begin{array}{l}\text { (boloke bo) Likawu } \\
(\mathrm{u}, \mathrm{o})\end{array}$ & $\begin{array}{l}\text { medicinal } \\
\text { tech \& mat } \\
\text { construction }\end{array}$ & $\begin{array}{l}\text { leaves: serpent bite (o) } \\
\text { liana: mats (o,u), beds (u) and fish fykes (o) } \\
\text { leaves: roof thatching (u) }\end{array}$ \\
\hline & Raphia sese De Wild. & ikolo, fande (u) & $\begin{array}{l}\text { construction } \\
\text { tech \& mat } \\
\text { fodder }\end{array}$ & $\begin{array}{l}\text { palm leaves: roof thatching }(\mathrm{u}) \\
\text { leaf veins: brooms }(\mathrm{u}) \\
\text { palm leaves: local beds }(\mathrm{u}) \\
\text { host tree for edible larvae }(\mathrm{u})\end{array}$ \\
\hline Asteraceae & $\begin{array}{l}\text { Crassocephalum crepidioides } \\
\text { (Benth.) S.Moore }\end{array}$ & limbiti $(u, w, o)$ & cultural & $\begin{array}{l}\text { 'bolenge' reduce female domination (love } \\
\text { charm) (u) }\end{array}$ \\
\hline \multirow[t]{2}{*}{ Burseraceae } & Canarium schweinfurthii Engl. & bobele, ibele $(\mathrm{u}, \mathrm{w}, \mathrm{o})$ & $\begin{array}{l}\text { tech \& mat } \\
\text { medicinal } \\
\text { fuels } \\
\text { cultural }\end{array}$ & $\begin{array}{l}\text { varnish }(\mathrm{w}) \\
\text { bark: back ache }(\mathrm{o}) \\
\text { resin: candles }(\mathrm{o}, \mathrm{w}, \mathrm{u}) \\
\text { resin: smoke to chase bad spirits }(\mathrm{u})\end{array}$ \\
\hline & $\begin{array}{l}\text { Dacryodes osika (Guillaumin) } \\
\text { H.J.Lam. }\end{array}$ & $\begin{array}{l}\text { ibele sawu, } \\
\text { isawusawu }(\mathrm{u}, \mathrm{w}, \mathrm{o})\end{array}$ & fuels & firewood $(\mathrm{w}, \mathrm{u})$ \\
\hline Clusiaceae & Mammea africana Sabine & boliti (o) & cultural & stimulate children to start to walk (o) \\
\hline Costaceae & $\begin{array}{l}\text { Costus lucanusianus J.Braun \& } \\
\text { K.Schum. }\end{array}$ & $\begin{array}{l}\text { bokako (bobaye) } \\
(\mathrm{u}, \mathrm{w}, \mathrm{o})\end{array}$ & $\begin{array}{l}\text { cultural } \\
\text { medicinal }\end{array}$ & $\begin{array}{l}\text { eating young leaf: problem solving (o) } \\
\text { stem sap: measles (o,w); injuries (w), syrup to } \\
\text { add other medicinal substances (u) } \\
\text { young plant: anti-poison (o) } \\
\text { leaf sap: amoeba (o) } \\
\text { bark: cords for transporting firewood (w) }\end{array}$ \\
\hline $\begin{array}{l}\text { Dennsteadtiaceae } \\
\text { (pteridophyta) }\end{array}$ & Pteridium aquilinum (L.) Kuhn & lilele (o) & medicinal & $\begin{array}{l}\text { young leaves: eye injuries (o) } \\
\text { young bud: remove thorns in feet (o) }\end{array}$ \\
\hline
\end{tabular}


tech \& mat whole plant: conservation of fish (o)

\begin{tabular}{|c|c|}
\hline Dichapetalaceae & Dichapetalum mombuttense Engl \\
\hline \multirow[t]{4}{*}{ Euphorbiaceae } & $\begin{array}{l}\text { Alchornea cordifolia (Schumach. } \\
\text { \& Thonn.) Müll.Arg. }\end{array}$ \\
\hline & $\begin{array}{l}\text { Erythrococca atrovirens (Pax) } \\
\text { Prain var. flaccida (Pax) Radcl.- } \\
\text { Sm. }\end{array}$ \\
\hline & Euphorbia hirta L. \\
\hline & $\begin{array}{l}\text { Tetracarpidium conophorum } \\
\text { (Müll.Arg.) Hutch. \& Dalziel }\end{array}$ \\
\hline $\begin{array}{l}\text { Fabaceae } \\
\text { (Caesalpinioideae } \\
\text { ) }\end{array}$ & $\begin{array}{l}\text { Gilbertiodendron dewevrei (De } \\
\text { Wild.) J.Léonard }\end{array}$ \\
\hline
\end{tabular}

ekpalanganga $(\mathrm{u}, \mathrm{o})$ lisungulingba/lisung uliteti $(\mathrm{w}, \mathrm{o})$

liondje $(\mathrm{u}, \mathrm{w}, \mathrm{o})$

(1)

likile $(\mathrm{w}, \mathrm{o})$

(1)

ngotoindika (o)

botito, tito $(\mathrm{u}, \mathrm{w}, \mathrm{o})$

mbolu, lofete $(\mathrm{u}, \mathrm{w}, \mathrm{o})$

促

\section{medicina}

poison

medicinal

branches: traps (w)

fruit juice: back ache (u)

medicinal young leaves: dental caries (o)

leaves: anaemia (u)

bait fruits: bait/poison for fish - $(\mathrm{w}, \mathrm{u})$-and birds (u)

cultural leave: wound healing after circumcision (u)

medicinal leaves: bruises (o), eye injuries (w)

bark: eye injuries (w)

medicinal

whole plant: amoeba (o), intestinal worms (o)

social

children put nut skin nut on forehead to play (u)

construction wood: planks (w,o,u)

leaves: roof thatching $(0, u)$

firewood (w)

tech \& mMat bark: 'sombotiti' local mortar (w, o)

trunk: mortar (o)

seeds: children's toy (u)

Scorodophloeus zenkeri Harms bofili $(\mathrm{u}, \mathrm{w}, \mathrm{o})$

(o)

Fabaceae Desmodium setigerum (E.Mey.)

(Papilionoideae) Benth. ex Harv.

Gnetaceae Gnetum africanum Welw.

ikpesaamuku (o)

cultural

fish poison (o)

bark: hernia (u), filariasis (u), ascaris (= roundworm infection) (u)

Huaceae

Hua gabonii Pierre ex De Wild.

fumbwa $(\mathrm{u}, \mathrm{w}, \mathrm{o})$

medicinal

root: luck charm for winning e.g. foot match (o)

lofiongi (u,w)

longowu $(\mathrm{w}, 0)$

medicinal

leaves: cholera (o)

leaves/liana: diarrhoea (o)

poison

fruit juice: amoeba (o)

leaves: cataract $(\mathrm{u})$

leaves in nose dog for good hunting (u)

Irvingiaceae

Irvingia smithii Hook.f.

bosombo $(\mathrm{w}, \mathrm{o})$

medicinal

root: strenghtener (o)

bark: back ache (o), intestinal worms (w)

aAAngbongbo(lia) cultural

(u,w,o)

medicinal

seeds: luck charm (o,w,u); solving problems (u)

Schott. \& Endl.

lLosakanu, sakanu

(u,w,o)

limbabaliyekondo

$(\mathrm{w}, \mathrm{o})$

Cola congolana De Wild. \&

losakanu, sakanu

(u,w,o)

limbabaliyekondo

$(\mathrm{w}, \mathrm{o})$

Cola marsupium K.Schum.

ŁŁosakanu, sakanu

(u,w,o)

limbabaliyekondo

$(\mathrm{w}, \mathrm{o})$

Cola urceolata K.Schum.

lŁosakanu, sakanu

(u,w,o)

limbabaliyekondo

$(\mathrm{w}, \mathrm{o})$

Hibiscus acetosella Welw. ex

damudamu (u) seeds: male potency $(0, \mathrm{u})$ seeds: hernia (o)

medicinal

roots: joint problems, rheumatism (o,u)

leaves: stimulating maternal milk production (o)

tech \& mMat branch: children's toy (gun) (o)

medicinal

roots: joint problems, rheumatism (o,u)

leaves: fish bone in throat (o)

leaves: stimulating maternal milk production (o)

tech \& $\underline{\text { mMat }}$ branch: children's toy (gun) (o)

medicinal

roots: joint problems, rheumatism (o,u)

leaves: fish bone in throat (o)

leaves: stimulating maternal milk production (o)

tech \& $\underline{\text { mMat }}$ branch: children’s toy (gun) (o)

medicinal

roots: joint problems, rheumatism $(\mathrm{o}, \mathrm{u})$

leaves: fish bone in throat (o)

leaves: stimulating maternal milk production (o)

tech \& mMat branch: children’s toy (gun) (o)

medicinal

leaves: anaemia (u)

cultural decoction of leaves as Christ's blood in church

(u) 


\begin{tabular}{|c|c|c|c|c|}
\hline \multirow[t]{3}{*}{ Marantaceae } & $\begin{array}{l}\text { Megaphrynium macrostachyum } \\
\text { (Benth.) Milne-Redh. }\end{array}$ & $\begin{array}{l}\text { (bolokebo)likongo, } \\
\text { beye }(\mathrm{u}, \mathrm{w}, \mathrm{o})\end{array}$ & $\begin{array}{l}\text { construction } \\
\text { tech \& mat }\end{array}$ & $\begin{array}{l}\text { leaves: roof tatching }(\mathrm{o}, \mathrm{w}, \mathrm{u}) \\
\text { leaves: packing material, plates }(\mathrm{o}, \mathrm{w}, \mathrm{u}) \\
\text { stems: mats, beds }(\mathrm{o}, \mathrm{w}, \mathrm{u})\end{array}$ \\
\hline & $\begin{array}{l}\text { Trachyphrynium braunianum (K. } \\
\text { Schum.) Baker }\end{array}$ & $\begin{array}{l}\text { ikokombeshalia, } \\
\text { bolikabwalima (w) }\end{array}$ & $\begin{array}{l}\text { tech \& mat } \\
\text { cultural }\end{array}$ & $\begin{array}{l}\text { leaves: packing the bait (o) } \\
\text { stems: good luck for fishermen (w) }\end{array}$ \\
\hline & & ikokombeibaye (o) & & \\
\hline Melastomataceae & $\begin{array}{l}\text { Tristemma mauritianum } \\
\text { J.F.Gmel. }\end{array}$ & $\begin{array}{l}\text { lituma lilokonda } \\
(\mathrm{u}, \mathrm{w}, \mathrm{o})\end{array}$ & $\begin{array}{l}\text { cultural } \\
\text { medicinal }\end{array}$ & $\begin{array}{l}\text { fruit: avoiding serpent bites }(\mathrm{o}, \mathrm{u}) \\
\text { leaves: intestinal worms }(\mathrm{o})\end{array}$ \\
\hline Menispermaceae & Penianthus longifolius Miers & l_tokumbo (o) & $\begin{array}{l}\text { medicinal } \\
\text { tech \& mat }\end{array}$ & $\begin{array}{l}\text { root: back ache (o), male potency } \\
\text { leaves: small part on bow to direct arrows (o) }\end{array}$ \\
\hline Moraceae & $\begin{array}{l}\text { Musanga cecropioides R.Br. ex } \\
\text { Tedlie }\end{array}$ & bBBokombo (o) & tech \& mat & trunk: beds (o), praus (o) \\
\hline Pandaceae & Panda oleosa Pierre & bakale $(\mathrm{u}, \mathrm{w}, \mathrm{o})$ & medicinal & $\begin{array}{l}\text { fruit: eye injury (o) } \\
\text { bark: buboes (= inflammation of lymph nodes } \\
\text { due to an STI or bubonic plague) (u) }\end{array}$ \\
\hline Passifloraceae & Passiflora foetida L. & maveve (u,w,o) & medicinal & measles (o) \\
\hline $\begin{array}{l}\text { Pentadiplandrace } \\
\text { ae }\end{array}$ & Pentadiplandra brazzeana Baill. & $\begin{array}{l}\text { etekele, amelalokulu } \\
(\mathrm{u}, \mathrm{w}, \mathrm{o})\end{array}$ & medicinal & $\begin{array}{l}\text { root: back ache, lumbago (o,w,u) malaria (o), } \\
\text { shingles (o), warm abscess (o), } \\
\text { gonorrhea (u), dental caries (u), measles (u), } \\
\text { scabies of dogs (u) } \\
\text { bark: fish poison }(\mathrm{o}, \mathrm{u})\end{array}$ \\
\hline \multirow[t]{2}{*}{ Phyllantaceae } & Hymenocardia ulmoides Oliv. & bokelele(w,o) & medicinal & $\begin{array}{l}\text { bark: serpent bite (o) } \\
\text { leaf decoction: stimulating maternal milk } \\
\text { production (o) }\end{array}$ \\
\hline & & & $\begin{array}{l}\text { construction } \\
\text { fuels }\end{array}$ & $\begin{array}{l}\text { branch: houses/fences (o,w) } \\
\text { firewood (w), charcoal (w) }\end{array}$ \\
\hline \multirow[t]{2}{*}{ Phytolaccaceae } & Hilleria latifolia (Lam.) H.Walter & lokobo $(\mathrm{u}, \mathrm{w}, \mathrm{o})$ & medicinal & leaves: asthma (o), swellings (o), felon (u) \\
\hline & Phytolacca dodecandra L'Hér. & lisingo $(\mathrm{u}, \mathrm{w}, \mathrm{o})$ & medicinal & stem: dental cariës (u) \\
\hline Piperaceae & $\begin{array}{l}\text { Piper guineense Schumach. \& } \\
\text { Thonn. }\end{array}$ & iketu $(\mathrm{u}, \mathrm{w}, \mathrm{o})$ & medicinal & $\begin{array}{l}\text { leave decoction: back ache }(\mathrm{o}, \mathrm{w}) \text {, cough (o) } \\
\text { roots: general pain (w) } \\
\text { fruits: cough (w) } \\
\text { liana/fruits: back and thorax ache (u) }\end{array}$ \\
\hline Polygalaceae & Carpolobia alba G.Don & lokembia $(w, 0)$ & medicinal & male potency (o) \\
\hline Portulacaceae & $\begin{array}{l}\text { Talinum triangulare (Jacq.) } \\
\text { Willd. }\end{array}$ & $\begin{array}{l}\text { melelu }(u) \\
\text { sese }(w, 0)\end{array}$ & $\begin{array}{l}\text { medicinal } \\
\text { fodder }\end{array}$ & $\begin{array}{l}\text { leaves: thorns in feet (o) } \\
\text { porc feed (u) }\end{array}$ \\
\hline \multirow[t]{2}{*}{ Rubiaceae } & $\begin{array}{l}\text { Sabicea johnstonii K.Schum. ex } \\
\text { Wernham }\end{array}$ & damudamu (o) & medicinal & fruit: anaemia (o) \\
\hline & $\begin{array}{l}\text { Sherbournia bignoniiflora } \\
\text { (Welw.) Hua }\end{array}$ & $\underline{I}$ tosabola $(\mathrm{u}, \mathrm{w}, \mathrm{o})$ & $\begin{array}{l}\text { cultural } \\
\text { medicinal }\end{array}$ & $\begin{array}{l}\text { leaves: reduce female domination (love } \\
\text { charm)(o) } \\
\text { leaves: gastritis (u) } \\
\text { roots: cough (u) }\end{array}$ \\
\hline Rutaceae & $\begin{array}{l}\text { Zanthoxylum macrophyllum Nutt. } \\
\text { var preussii Engl. }\end{array}$ & bBBolongo (o) & medicinal & $\begin{array}{l}\text { bark decoction: back ache (o), malaria (o), } \\
\text { cough (o), general weakness (o) }\end{array}$ \\
\hline Sapindaceae & $\begin{array}{l}\text { Pancovia laurentii (De Wild.) } \\
\text { Gilg ex De Wild. }\end{array}$ & $\begin{array}{l}\text { botende, ntende } \\
(\mathrm{u}, \mathrm{w}, \mathrm{O})\end{array}$ & $\begin{array}{l}\text { tech \& mat } \\
\text { fuels }\end{array}$ & $\begin{array}{l}\text { latex: balls for children (o) } \\
\text { firewood (w) }\end{array}$ \\
\hline \multirow[t]{3}{*}{ Sapotaceae } & $\begin{array}{l}\text { Chrysophyllum lacourtianum De } \\
\text { Wild. }\end{array}$ & $\begin{array}{l}\text { bolinda, lilinda } \\
(\mathrm{u}, \mathrm{w}, \mathrm{o})\end{array}$ & $\begin{array}{l}\text { construction } \\
\text { fuels } \\
\text { medicinal }\end{array}$ & $\begin{array}{l}\text { trunk: house pillar (w) } \\
\text { firewood (w) } \\
\text { bark: stimulating maternal milk production (u) }\end{array}$ \\
\hline & $\begin{array}{l}\text { Synsepalum brevipes (Baker) } \\
\text { T.D.Penn. }\end{array}$ & $\begin{array}{l}\text { bokokolo, ikokolo } \\
(\mathrm{w}, \mathrm{o})\end{array}$ & medicinal & bark: back ache (o) \\
\hline & $\begin{array}{l}\text { Synsepalum stipulatum (Radlk.) } \\
\text { Engl. }\end{array}$ & bonga, tonga $(\mathrm{u}, \mathrm{w}, \mathrm{o})$ & fuels & firewood (w) \\
\hline
\end{tabular}




\begin{tabular}{|c|c|c|c|c|}
\hline Smilacaceae & Smilax anceps Willd. & likako $(\mathrm{u}, \mathrm{w}, \mathrm{o})$ & cultural & $\begin{array}{l}\text { liana around house protects against nightmares } \\
\text { (o) }\end{array}$ \\
\hline \multirow[t]{2}{*}{ Solanaceae } & Capsicum frutescens L. & $\begin{array}{l}\text { mMbase ikukunde } \\
(\mathrm{w}, \mathrm{o})\end{array}$ & medicinal & $\begin{array}{l}\text { leaves: abscess (o), felon (o), ear inflammation } \\
\text { (o) } \\
\text { Fruit: constipation (o), enema mother after } \\
\text { childbirth (w) }\end{array}$ \\
\hline & $\begin{array}{l}\text { Solanum aethiopicum L. } \\
\text { "gilo group" }\end{array}$ & $\underline{l}$ Losuke $(\mathrm{w}, \mathrm{o})$ & medicinal & $\begin{array}{l}\text { fruit: anti-poison (o) } \\
\text { roots: to close fontanel of newborns (o) }\end{array}$ \\
\hline Tiliaceae & $\begin{array}{l}\text { Desplatsia dewevrei (De Wild. \& } \\
\text { T.Durand) Burret }\end{array}$ & $\begin{array}{l}\text { bokomba, likamba } \\
\text { (u) } \\
\text { lisuli }(\mathrm{w}, \mathrm{o})\end{array}$ & tech \& mat & $\begin{array}{l}\text { fruit: protect fishermen (w), drive away } \\
\text { hippopotamus (u), chasing mosquitoes (o), } \\
\text { permits pregnant women to enter the tomato } \\
\text { fields (o) } \\
\text { bark: basks (u) }\end{array}$ \\
\hline Urticaceae & Myrianthus arboreus P.Beauv. & $\begin{array}{l}\text { bongunguna (u) } \\
\text { bohuma }(w, o)\end{array}$ & $\begin{array}{l}\text { medicinal } \\
\text { cultural } \\
\text { fuels }\end{array}$ & $\begin{array}{l}\text { leaves: anti-poison (o) } \\
\text { bark: anti-domination product (o) } \\
\text { firewood (w) }\end{array}$ \\
\hline Verbenaceae & $\begin{array}{l}\text { Vitex congolensis De Wild. \& } \\
\text { T.Durand }\end{array}$ & ebite (o) & $\begin{array}{l}\text { construction } \\
\text { medicinal }\end{array}$ & $\begin{array}{l}\text { sticks for houses or fences (o) } \\
\text { leaves: tuberculosis (o) }\end{array}$ \\
\hline Vitaceae & $\begin{array}{l}\text { Cyphostemma adenocaule (Steud. } \\
\text { ex A.Rich.) Desc. ex Wild \& } \\
\text { R.B.Drumm. }\end{array}$ & bombeye (o) & medicinal & $\begin{array}{l}\text { leaves: head ache (o) } \\
\text { roots: abscess (o) }\end{array}$ \\
\hline Zingiberaceae & $\begin{array}{l}\text { Aframomum laurentii (De Wild. } \\
\text { \& T.Durand) K.Schum. }\end{array}$ & $\begin{array}{l}\text { bongongoo, soso } \\
(\mathrm{u}, \mathrm{w}, \mathrm{o})\end{array}$ & medicinal & $\begin{array}{l}\text { fruit: filariasis (o), syrup to add other medicinal } \\
\text { substances }(\mathrm{u}, \mathrm{o}) \\
\text { fruit pulp: general pain (w) }\end{array}$ \\
\hline
\end{tabular}

(u), (w) and (o) vernacular name(s) under which the plant species is known and used in Yalungu, Yasekwe and Yaoseko, respectively.

2 (u), (w) and (o) other uses registrated in Yalungu, Yasekwe and Yaoseko, respectively.

3 category: technology, materials and arts 
Table 5 : Aggregated results of the participatory ranking exercises for fruits. Numbers represent number of times a plant species appeared in the top three for the different characteristics (taste, economic value, socio-cultural value or nutritional value) and in the global weighted ranking.

\begin{tabular}{|l|c|c|c|c|c|}
\hline \multicolumn{1}{|c|}{ Fruits } & Taste & $\begin{array}{c}\text { Economic } \\
\text { Value }\end{array}$ & $\begin{array}{c}\text { Socio-cultural } \\
\text { value }\end{array}$ & $\begin{array}{c}\text { Nutritional } \\
\text { value }\end{array}$ & $\begin{array}{c}\text { Global } \\
\text { weighted } \\
\text { ranking }\end{array}$ \\
\hline Aframomum laurentii & 0 & 1 & 2 & 0 & 0 \\
\hline Anonidium mannii & $\mathbf{4}$ & $\mathbf{5}$ & $\mathbf{4}$ & $\mathbf{6}$ & $\mathbf{6}$ \\
\hline $\begin{array}{l}\text { Chrysophyllum } \\
\text { lacourtianum }\end{array}$ & 0 & 3 & 1 & 4 & 2 \\
\hline Landolphia owariensis & $\mathbf{4}$ & $\mathbf{5}$ & 0 & 3 & 4 \\
\hline $\begin{array}{l}\text { Pentadiplandra } \\
\text { brazzeana }\end{array}$ & 3 & 1 & 2 & 0 & 1 \\
\hline Synsepalum stipulatum & 3 & 1 & 1 & 0 & 0 \\
\hline $\begin{array}{l}\text { Tetracarpidium } \\
\text { conophorum }\end{array}$ & 2 & 2 & 0 & 3 & 2 \\
\hline
\end{tabular}

Table 6 : Aggregated results of the participatory ranking exercises for vegetables. Numbers represent number of times a plant species appeared in the top three for the different characteristics (taste, economic value, socio-cultural value or nutritional value) and in the global weighted ranking.

\begin{tabular}{|l|l|l|l|l|l|}
\hline Vegetables & Taste & $\begin{array}{c}\text { Economic } \\
\text { Value }\end{array}$ & $\begin{array}{c}\text { Socio-cultural } \\
\text { value }\end{array}$ & $\begin{array}{c}\text { Nutritional } \\
\text { value }\end{array}$ & $\begin{array}{c}\text { Global } \\
\text { weighted } \\
\text { ranking }\end{array}$ \\
\hline Celosia spp. & 3 & 1 & 0 & 4 & 2 \\
\hline $\begin{array}{l}\text { Crassocephalum } \\
\text { crepidioides }\end{array}$ & 0 & 0 & 2 & 1 & 0 \\
\hline Gnetum africanum & 0 & 2 & 1 & 0 & 2 \\
\hline Hilleria latifolia & 0 & 0 & 2 & 0 & 0 \\
\hline Hua gaboni & 5 & 4 & $\mathbf{5}$ & 1 & 2 \\
\hline $\begin{array}{l}\text { Megaphrynium } \\
\text { macrostachyum }\end{array}$ & 4 & $\mathbf{6}$ & 2 & $\mathbf{6}$ & $\mathbf{6}$ \\
\hline Scorodophloeus zenkeri & 1 & 4 & 4 & 1 & 1 \\
\hline Talinum triangulare & $\mathbf{6}$ & 2 & 0 & $\mathbf{6}$ & $\mathbf{4}$ \\
\hline
\end{tabular}

